

\section{Daftar Isi (Table of Content) Journal of Government
Civil Society}

\begin{tabular}{|c|c|}
\hline \multirow{3}{*}{$1-34$} & $\begin{array}{l}\text { Akuntabilitas Politik dalam Anggaran (Studi Kasus: Dana Gerakan Dusun } \\
\text { Membangun (GDM) di Kabupaten Bungo) }\end{array}$ \\
\hline & Fajar Trilaksana Moedarlis \\
\hline & (Magister Ilmu Pemerintahan, Universitas Muhammadiyah Yogyakarta, Indonesia) \\
\hline \multirow[b]{3}{*}{$35-46$} & $\begin{array}{l}\text { Civil Servants Performance Analysis of Education, Youth and Sports } \\
\text { Department in Bantul District } 2017\end{array}$ \\
\hline & Surya Jaya Abadi ${ }^{1}$, Muhammad Eko Atmojo ${ }^{2}$, Helen Dian Fridayani ${ }^{3}$ \\
\hline & $\begin{array}{l}\left({ }^{1} \text { Government Affairs and Administration, Universitas Muhammadiyah Yogyakarta, }\right. \\
\text { Indonesia) } \\
\text { ('2Government Affairs and Administration, Universitas Muhammadiyah Yogyakarta, } \\
\text { Indonesia) } \\
\text { ('3overnment Affairs and Administration, Universitas Muhammadiyah Yogyakarta, } \\
\text { Indonesia) }\end{array}$ \\
\hline \multirow{3}{*}{$47-61$} & $\begin{array}{l}\text { Efektivitas Pengawasan Badan Pengawas Obat dan Makanan (BPOM) } \\
\text { terhadap Peredaran Makanan Impor oleh Pedagang UMKM di Kota } \\
\text { Pekanbaru }\end{array}$ \\
\hline & Ferry Angriawan1, Dyah Mutiarin² \\
\hline & $\begin{array}{l}\text { ('Magister Ilmu Pemerintahan, Universitas Muhammadiyah Yogyakarta, Indonesia) } \\
\left({ }^{2} \text { Magister Ilmu Pemerintahan, Universitas Muhammadiyah Yogyakarta, Indonesia) }\right.\end{array}$ \\
\hline \multirow{3}{*}{$63-78$} & $\begin{array}{l}\text { Institusionalisasi Partai Politik dalam Pilkada } 2017 \text { (Studi Kasus: Partai } \\
\text { Golkar Provinsi Kepulauan Bangka Belitung) }\end{array}$ \\
\hline & Agam Primadi ${ }^{1}$, Titin Purwaningsih ${ }^{2}$ \\
\hline & $\begin{array}{l}\left({ }^{1} \text { Magister Ilmu Pemerintahan, Universitas Muhammadiyah Yogyakarta, Indonesia) }\right. \\
\left({ }^{2} \text { Magister Ilmu Pemerintahan, Universitas Muhammadiyah Yogyakarta, Indonesia) }\right.\end{array}$ \\
\hline \multirow[b]{3}{*}{$79-91$} & $\begin{array}{l}\text { Public Value in Clean Water Management at the Local Water Supply Utility } \\
\text { (PDAM) Tirta Kerta Raharja (TKR) }\end{array}$ \\
\hline & Arsid $^{1}$, Ida Widianingsih'², Heru Nurasa ${ }^{3}$, Entang Adhy Muhtar ${ }^{4}$ \\
\hline & $\begin{array}{l}\text { ('Mahasiswa Program Pascasarjana Administrasi Publik, FISIP Universitas Padjadjaran, } \\
\text { Indonesia) } \\
\text { ('Pusat Studi Desentralisasi dan Pembangunan Partisipatif, FISIP Universitas } \\
\text { Padjadjaran, Indonesia) } \\
\text { ('Departemen Administrasi Publik, FISIP Universitas Padjadjaran, Indonesia) } \\
\left({ }^{4} \text { Departemen Administrasi Publik, FISIP Universitas Padjadjaran, Indonesia) }\right.\end{array}$ \\
\hline
\end{tabular}




\title{
Akuntabilitas Politik dalam Anggaran (Studi Kasus: Dana Gerakan Dusun Membangun (GDM) di Kabupaten Bungo)
}

\author{
Fajar Trilaksana Moedarlis \\ Magister Ilmu Pemerintahan, Universitas Muhammadiyah Yogyakarta, Indonesia \\ Email: fajaracit@gmail.com
}

\begin{abstract}
ABSTRAK
Pemerintahan Kabupaten Bungo dalam menjawab janji politik Bupati terpilih membuat sebuah kebijakan melalui Peraturan Bupati Bungo Nomor 5 Tahun 2017 Tentang Pedoman Umum dan Petunjuk Teknis Program Gerakan Dusun Membangun (GDM), yaitu memberikan bantuan keuangan kepada dusun sejumlah Rp 250.000.000 per dusun. Pelaksanaannya dikelola berdasarkan asas-asas transparan, akuntabel, partisipatif serta dilakukan dengan tertib dan disiplin anggaran. Dalam melakukan penelitian tentang Akuntabilitas Politik Dalam Anggaran Publik (Studi Kasus: Pengelolaan Dana Dusun Membengun (GDM) di Kabupaten Bungo ini, menggunakan Metode Penelitian Deskriptif Kualitatif. Adapun alasan penelitian ini menggunakan pendekatan kualitatif adalah karena dalam penelitian ini data yang dihasilkan berupa data deskriptif yang diperoleh dari data-data berupa tulisan, kata-kata dan dokumen yang berasal dari sumber atau informan yang berkaitan dengan akuntabilitas politik ini dan stakeholder yang dapat dipercaya. Hasil analisis dari penelitian ini, bahwa Pemerintah Kabupaten Bungo telah Akuntabel dalam merealisasikan janji politiknya. Kemudian Dusun Lubuk Beringin dan Tombolasi telah sama-sama akuntabel dalam penggunaan dana GDM. Namun hal yang berbeda terdapat di Dusun Sinamat Ulu Pemerintahan ini sama sekali tidak akuntabel, karena realisasi anggaran yang fiktif. Kabupaten sebaiknya dapat memberikan sistem yang lebih ringkas dan mudah untuk diaplikasikan oleh Pemerintah Dusun namun dapat di petanggungjawabkan.
\end{abstract}

Kata Kunci: Akuntabilitas politik, GDM, pemerintah dusun

\begin{abstract}
The Bungo District Government in responding to the political promises of the elected Regent made a policy through the Bungo Regent Regulation Number 5 of 2017 concerning General Guidelines and Technical Guidelines for the Building Hamlet Movement Program (GDM), namely providing financial assistance to hamlets in the amount of $R p$ 250,000,000 per hamlet. The implementation is managed based on transparent, accountable, participatory principles and carried out in an orderly and budgetary discipline. In conducting research on Political Accountability in Public Budgets (Case Study: Management of Membengun Hamlet Funds (GDM) in Bungo District, using Qualitative Descriptive Research Methods. The reason for this study using a qualitative approach is because in this study the data generated are descriptive data obtained from data in the form of writing, words and documents originating from sources or informants related to this political accountability and trustworthy stakeholders. The results of the analysis of this study, that the Bungo District Government has been Accountable in realizing its political promises. Lubuk Beringin and Tombolasi have been equally accountable in using GDM funds, but different things are found in the Sinamat Ulu Hamlet. This government is totally unaccountable, because the budget realization is fictitious. The district should be able to provide a system that is more concise and easier to apply by Hamlet Government but can be accounted for.
\end{abstract}

Keywords: Political accountability, GDM, hamlet government

Citation : Moedarlis, Fajar Trilaksana. 2019. “Akuntabilitas Politik dalam Anggaran (Studi Kasus: Dana Gerakan Dusun Membangun (GDM) di Kabupaten Bungo)". Journal of Government and Civil Society, Vol.3, No. 1, 1-34. 


\section{PENDAHULUAN}

Hakikatnya politik adalah segala aktivitas dimana manusia berusaha untuk meningkatkan kehidupan mereka, mensejahterakan, dan menciptakan masyarakat yang baik, dan yang terpenting politik adalah sebuah aktivitas sosial. Dalam politik ada beberapa ideologi yang digunakan sebagai landasan aksi politik itu sendiri untuk mewujudkan masyarakat yang lebih baik. Salah satunya yang banyak digunakan oleh negara-negara di dunia dalam upaya mesejahterkan masyarakatnya adalah ideologi demokrasi karena demokrasi merupakan kata yang paling menjanjikan dalam urusan publik (Andre heywood 2013:152).

Makna-makna yang telah dilekatkan pada kata demokrasi adalah sebagai berikut (Bernard Crick, 1993): (1) Sebuah sistem kekuasaan oleh yang miskin dan yang kurang beruntung, (2) satu bentuk pemerintah dimana rakyat memerintah diri mereka sendiri secara langsung dan terus-menerus, tanpa membutuhkan para politisi profesional atau pejabat-pejabat publik, (3) sebuah masyarakat yang didasarkan pada kesetaraan kesempatan dan kebaikan individu dari pada hierarki dan hak istimewa, (4) sebuah sistem kesejahteraan dan redistribusi yang bertujuan untuk mengurangi ketidaksetaraan sosial, (5) sebuah sistem pembuatan keputusan yang didasarkan pada prinsip aturan mayoritas (6) sebuah sistem yang menjamin hak-hak dan kepentingan dari minoritas dengan memberlakukan pengawasan dan pemeriksaaan pada kekuasaan dari mayoritas (7) sebuah cara dalam mengisi jabatan-jabatan publik melalui kompetisi memperoleh suara (8) sebuah sistem pemerintahan yang melayani kepentingan-kepentingan dari rakyat tanpa memandang partisipasi mereka dalam kehidupan politik.

Meskipun terus terdapat kontroversi tentang bentuk demokrasi yang paling diinginkan seputar bagaimana demokrasi berjalan dalam peraktiknya, namun yang paling mendapat penerimaan yang luas dari seluruh dunia adalah demokrasi liberal. Demokrasi liberal adalah satu bentuk demokrasi yang bersifat tidak langsung dan perwakilan, dan dimana jabatan politik diperoleh melalui pemilihan-pemilihan yang dilaksanakan secara berkala, toleransi terhadap beragam keyakinan, dan dicirikan pembedaan yang jelas antara negara dan masyarakat sipil, menyediakan perlindungan bagi individu-individu dan kelompok minoritas terutama melalui pemberian hak-hak dasar yang melindungi mereka dari kehendak mayoritas (Andre heywood, 2013: 170).

Ideologi demokrasi ini yang juga di adopsi oleh Indonesia pasca orde baru yang menjadikan sistem politik yang berubah, tidak lagi sistem satu tengah partai melainkan sistem multipartai. Munculnya perubahan di dalam sistem kepartaian dan sistem pemilu itu, paling tidak, telah membuka ruang yang lebih besar kepada warga negara untuk terlibat lebih aktif di arena politik. Contohnya adalah perubahan itu telah memungkinkan adanya aktor-aktor baru di arena politik, baik di tingkat nasional maupun di tingkat lokal. Demokrasi tentu saja tidak semata-mata adanya pemilu yang bebas, di dalam sistem 
perwakilan, demokrasi juga menuntut adanya pertanggungjawaban (akuntabilitas) dari wakil (representative) kepada yang diwakili (reprensented) (Hungtington, 1991: 9 di dalam Prof. Dr. Kacung Marijan, 2010: 11). Termasuk pertanggungjawaban terhadap janjijanji seorang aktor politik ketika dalam berkampanye Setelah terpilih menjadi pejabat publik. Pejabat publik harus merealisasikan janji-janji itu dan mempertanggungjawabkan pelaksanaannya baik secara terbuka, moral, teknis, legal, maupun admistratif.

Pemerintahan Kabupaten Bungo khususnya dalam menjawab janji politik Bupati terpilih yaitu memberikan bantuan keuangan kepada dusun sejumlah Rp 250.000.000 per dusun, serta untuk melaksanakan ketentuan Undang Undang Nomor 6 Tahun 2014 Tentang Desa, maka membuat sebuah kebijakan melalui Peraturan Bupati Bungo Nomor 5 Tahun 2017 Tentang Pedoman Umum dan Petunjuk Teknis Program Gerakan Dusun Membangun (GDM), yaitu untuk memperkuat pelaksanaan bantuan keuangan oleh Pemerintah Kabupaten Bungo kepada dusun untuk meningkatkan kesejahteraaan masyarakat miskin di dusun. Dana GDM tersebut bersumber dari APBD Kabupaten Bungo yang bersifat khusus, dan yang menerima dana GDM tersebut adalah seluruh Dusun yang ada di Kabupaten Bungo yang berjumlah 141 dusun dengan namun alokasi dana GDM yang diterima oleh setiap dusun untuk tahun anggaran 2017 sebesar Rp.150.000.000, yang dicairkan 2 (dua) tahap. Tahap I sebesar 50\% (lima piluh perseratus) dan tahap II sebesar 50\% (lima puluh perseratus), yang di kelola dalam masa 1 tahun yaitu dari 1 januari sampai dengan 31 Desember.

Kebijakan GDM tersebut merupakan hal yang strategis bagi Pemerintah Dusun. Maka apa yang terjadi di dusun sebenarnya menunjukan bagaimana pola akuntabilitas pemangku jabatan politik dari tingkat kabupaten hingga dusun yang mana dalam pelaksanaan dan pengelolaan keuangan dusun harus dikelola berdasarkan asas-asas transparan, akuntabel, partisipatif serta dilakukan dengan tertib dan disiplin anggaran, namun ada kondisi berbeda yang terjadi didalam pengelolaan dana Gerakan Dusun Membangun (GDM) di Kabupaten Bungo ini.

Tiga Dusun di Kabupaten Bungo, Kecamatan Bathin III Ulu, tidak bisa lagi mencairkan dana Gerakan Dusun Membangun (GDM) tahap II karena tidak memiliki waktu yang cukup untuk pengerjaan pembangunan fisik. Tiga Dusun itu adalah Dusun Lubuk Beringin, Dusun Senamat Ulu dan Dusun Timbolasi. Permasalahan di Dusun Senamat Ulu dan Dusun Timbolasi adalah aparatur dari kedua dusun tersebut tidak ada berkoordinasi dengan pihak DPMD terkait pencairan dana GDM tahap ke dua sehingga Pemerintah Kabupaten menganggap bahwa dana GDM tahap satu yang cairkan sudah cukup. Sementara untuk Dusun Lubuk Beringin, masih memiliki sisa pengerjaan anggaran yang belum terselesaikan dengan anggaran pada tahap I (satu) lalu sehingga pekerjaan tersebut masih diberi waktu pengerjaan sampai akhir Desember, hal ini menyebabkan Dana GDM tidak dapat dicairkan sehingga menunda pembangunan yang seharusnya 
bisa lebih efektif (Berita Harian Radar Bute, 19/12/2017). Kemudian di Dusun Sinamat Ulu masyarakat juga melaporkan kepala desa kepada Bupati bahwa Kepala Dusun Senamat Ulu tidak pernah transparan dalam penggunaan Dana desa (tribun news Jambi 2017/11/30).

Melihat dari beberapa masalah tersebut tentu saja dalam hal ini masih ada indikasi atau potensi yang masih bisa ditemukan dalam proses akuntabilitas pengelolaan Dana GDM di Kaupaten Bungo. Maka dalam mewujudkan pemerintahan yang akuntabel melalui penelitian ini berupaya mendapatkan informasi lebih dalam untuk mengetahui proses akuntabilitas politik dari program Gerakan Dusun Membangun (GDM) ini, di Dusun Lubuk Beringin, Dusun Senamat Ulu dan Dusun Timbolasi.

\section{KERANGKA TEORI}

\section{Akuntabilitas Politik}

Akuntabilitas politik adalah apa dan bagaimana mereka yang berkuasa bertanggung jawab kepada publik atas keputusan mereka. Hal ini membantu untuk menyorot akuntabilitas yang tidak hanya merupakan seperangkat mekanisme kelembagaan atau checklist prosedur, namun juga sebagai tanggungjawab yang harus di pertanggungjawabkan. Artinya bahwa para pejabat publik beserta organisasi sektor publik, harus benar-benar bertanggung jawab dan berkomitmen atas tindakan dan janjijanji mereka, ketika kampanye serta siap menerima konsikuensi jika ada yang tidak sesuai dengan semestinya (fox, 2007: 1-2).

Akuntabilitas politik memiliki beberapa unsur sebagai berikut (Jonathan Fox, 2017):

1. PertamaPetanggungjawaban Legal, yaitu Adanya legalitas dari setiap tindakan pejabat politikdan segala tindakan yang tidak sesuai dengan ketentuan dapat di pertanggungjawabkan secara hukum.

2. Adanya kebenaran dalam merealisasikan janji kampanye, yaitu para pejabat publik beserta organisasi sektor publik, harus benar-benar bersinergi dalam merealisasikan apa yang menjadi keputusan pejabat politik dari awal.

3. Adanya legalitas pertanggungjawaban pelaksanaan, yaitu adanya peraturan atau perundang-undangan yang mengikat dan mengatur dalam merealisasikan keputusan pejabat politik terhadap publik.

4. Adanya komitmen dalam pertanggungjawaban yaitu adanya komitmen pejabat politik dalam melaksanakan keputusan yang telah ditentukan.

5. Adanya trasnparansi, yaitu adanya keterbukaan kepada publik terhadap pelaksanaan keputusan pejabat politik. 
Akuntabilitas politik dikonseptualisasikan sebagai 'hasil' publik sesuatu yang pada dasarnya harus diberikan kepada masayarakat sebagai hasil dari kinerja pemerintah yang berfokus pada ideologi dan prosedur program anti kemiskinan. Proses ini berlangsung karena pada dasarnya masyarakat sungguh merupakan klien dari suatu pemerintahan. Untuk mendorong akuntabilitas, masyarakat sipil dan aktor negara secara efektif harus memberdayakan satusama lain dan kemudian menanamkan reformasi ini di dalam negara untuk suatu negara lebih akuntabel dan masyarakat mendapatkan hak haknya yang sah.

Akuntabilitas politik bertujuan untuk mencegah terjadinya kebocoran anggaran dan perlu sebuah sistem yang harus mengontrol kinerja pemerintah dengan memberikan pertanggungjawaban apa yang telah dilakukannya. Maka yang terpenting dari akuntabiltas adalah untuk mendapatkan harapan yang lebih baik terhadap kinerja dan pertanggungjawaban pemerintah. Kemudian memastikan bahwa Dana publik dihabiskan secara ilegal. Akuntabilitas juga harus mengacu pada apakah Dana publik digunakan secara efektif dan efisien.

\section{Keuangan Publik}

Keuangan publik merupakan keseluruhan undang-undang yang ditetapkan secara periodik yang memberikan kekuasaan pemerintah untuk menyelenggarakan, pengurusan, pertanggungjawaban, pengawasan keuangan publik, tugas dari pemerintah daerah khususnya dalam keuangan publik adalah menunjukan sumber-sumber pendapatan daerah, dan yang menentapkan Anggaran Pendapatan dan Belanja Daerah (APBD) pembiayaaan yang diperlukan untuk menutupi pengeluaran belanja pemerintah.

Sehubungan dengan pengertian keuangan publik memiliki pengertian yang sama dengan anggaran (budget) ditinjau dari anggaran negara, penyelenggaraan negara berati berkaitan dengan penyelenggaran anggaran di daerah. Keuangan daerah adalah semua hak dan kewajiban yang dapat dinilai dengan uang, juga segala kesatuan, baik berupa uang maupun barang, yang dapat dijadikan kekayaan daerah sepanjang belum dimiliki atau dikuasai oleh negara atau daerah yang lebih tinggi serta pihak-pihak lain sesuai ketentuan dan peraturan perundangan yang berlaku (Mames, 1995, di dalam halim, 2012 : 24). Hak merupakan hak daerah untuk mencari sumber pendapatan daerah berupa memungut pajak daerah, retribusi daerah atau sumber-sumber penerimaan lain yang sesuai dengan ketentuan perundangan yang berlaku. Sedangkan kewajiban adalah kewajiban daerah untuk mengeluarkan uang dalam rangka melaksanakan semua urusan pemerintahan di daerah. Sumber pendapatan daerah adalah, sebagai berikut (Halim, $2012: 10)$ : 
1. Pendapatan asli daerah

2. Hasil pajak

3. Hasil restribusi

4. Hasil pengelolaan kekayaan daerah yang dipisahkan

5. Lain-lain pendapatan daerah yang sah

6. Pendapatan transfer yang terdiri dari:

a. Transfer pemerintah pusat atau dana perimbangan yaitu dana bagi hasil pajak, dana bagi hasil sumber daya alam, dana alokasi umum, dan alokasi dana kusus.

b. Transfer pemerintah pusat lainya yaitu dana otonomi khusus dan dana penyesuaian.

c. Transfer pemerintah provinsi yaitu pendapatan bagi hasil pajak, pendapatan bagi hasil lainnya.

d. Lain-lain pendapatan daerah yang sah

Ketika membahas keuangan daerah tidak dapat dilepaskan dari pembahasan mengenai pengelolaan keuangan daerah. Pengelolaan keuangan daerah adalah seluruh kegiatan yang meliputi perencanaan, pelaksanaan, penatausahaan, pelaporan, pertanggungjawaban, dan pengawasan. Berdasarkan UU 33 Tahun 2004 pasal 66 ayat 1, keuangan daerah harus dikelola secara tertib, taat pada peraturan perundangundangan, efisien, ekonomis, efektif, transparan, dan bertanggungjawab dengan memperhatikan keadilan, kepatuta, dan manfaat untuk masyarakat. oleh karena itu, pengelolaan keuangan daerah dilaksanakan dengan pendekatan kinerja yang berorietasi pada output, dengan menggunakan konsep nilai uang (value for money) serta tata pemerintahan yang baik (good governance).

Mekanisme pengelolaan keuangan daerah terdiri dari mekanisme pendapatan dan belanja. Pendapatan daerah adalah hak pemerintah yang dapat dinilai dengan uang, juga segala satuan, baik berupa uang maupun barang yang dapat dijadikan kekayaan daerah sepanjang belum dimiliki negara, atau daerah yang lebih tinggi atau pihak-pihak lain yang yang sesuai dengan ketentuan perundang-undangan yang berlaku (Halim, 2012 : 24). Sumber pendapatan daerah adalah, sebagai berikut:

1. Pendapatan asli daerah

2. Hasil pajak

3. Hasil restribusi

4. Hasil pengelolaan kekayaan daerah yang dipisahkan 
5. Lain-lain pendapatan daerah yang sah

6. Pendapatan transfer yang terdiri dari:

a. Transfer pemerintah pusat atau dana perimbangan yaitu dana bagi hasil pajak, dana bagi hasil sumber daya alam, dana alokasi umum, dan alokasi dana kusus.

b. Transfer pemerintah pusat lainya yaitu dana otonomi khusus dan dana penyesuaian.

c. Transfer pemerintah provinsi yaitu pendapatan bagi hasil pajak, pendapatan bagi hasil lainnya.

d. Lain-lain pendapatan daerah yang sah

Mekanisme APBD dapat dilihat dari Pendapatan dan Belanja pemerintahan daerah. Rencana pendapatan yang telah ditetapkan dibagi berdasarkan kemungkinan realisasinya dalam bentuk anggaran kas (cas budget). Realisasi dari pendapatan daerah masuk ke dalam kas daerah. Anggaran kas menjadi pedoman dalam melakukan pengeluaran dikarenakan adanya fluktuasi dalam realisasi penerimaan. Belanja dalam APBD dibedakan menjadi belanja rutin dan belanja pembangunan.Atas dasar DIKDA/DIPDA, diterbitkan SKO dan selanjutnya SPMU yang digunakan ke kas daerah.

Namun mekanisme APBD banyak mengalami perubahan untuk memenuhi tuntutan akan transparansi dan akuntabilitas. Dokumen terkait dengan APBD dan proses akuntansi mengalami banyak penyempurnaan . dokumen terkait dengan penatausahaan keuangan daerah antara lain SPP, SPM, Surat Pencairan Dana (SP2D). SPP dan SPM kemuadian dibedakan berdasarkan tujuannya menjadi empat, yaitu uang persediaan (UP), ganti uang persediaan (GU), tambahan uang persediaan (TU) dan langsung (LS).

\section{Pengelolaan Keuangan Desa}

Pengelolaan Keuangan Desa adalah keseluruhan kegiatan yang meliputi perencanaan, pelaksanaan, penatausahaan, pelaporan, dan pertanggungjawaban keuangan desa. 


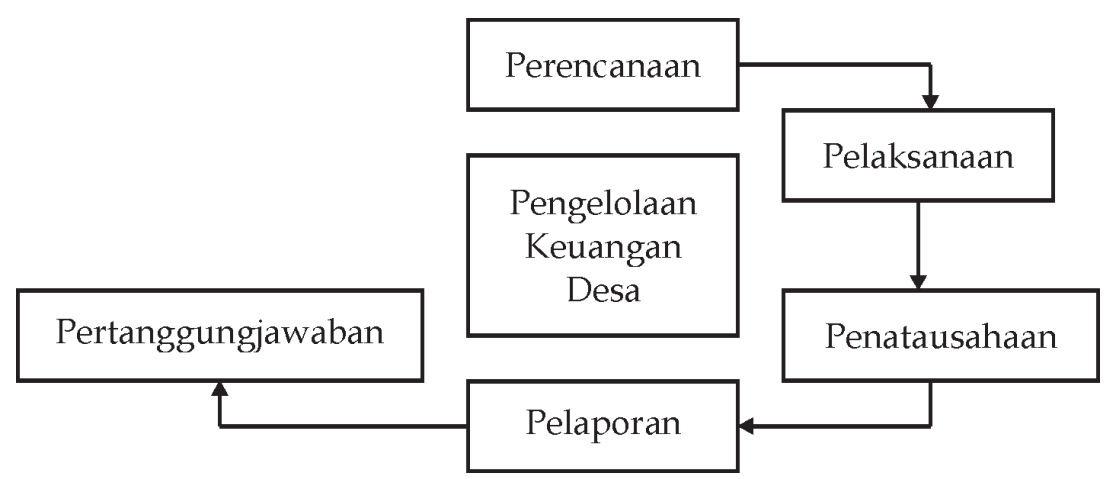

Gambar 1. Model Siklus Pengelolaan Keuangan Desa

Gambar di atas menjelaskan bagaimana siklus dalam proses Pengelolaan keuangan yaitu (Doddy, 2015. Hal :2-4) :

1. Perencanaan

Perencanaan Pembangunan Desa meliputi RPJM Desa dan RKP Desa yang disusun secara berjangka dan ditetapkan dengan Peraturan Desa. Rencana Pembangunan Jangka Menengah Desa (RPJM Desa) untuk jangka waktu 6 (enam) tahun sedangkan Rencana Pembangunan Tahunan Desa atau yang disebut Rencana Kerja Pemerintah Desa (RKP Desa) untuk jangka waktu 1 (satu) tahun. RKP Desa merupakan penjabaran dari Rencana Pembangunan Jangka Menengah Desa. Perencanaan pembangunan desa disusun berdasarkan hasil kesepakatan dalam musyawarah desa yang pelaksanaannya paling lambat pada bulan Juni tahun anggaran berjalan.

2. Penganggaran

Setelah RKP Desa ditetapkan maka dilanjutkan proses penyusunan APB Desa. Rencana Kegiatan dan Rencana Anggaran Biaya yang telah ditetapkan dalam RKP Desa dijadikan pedoman dalam proses penganggarannya. Anggaran Pendapatan dan Belanja Desa (APB Desa) merupakan rencana anggaran keuangan tahunan pemerintah desa yang ditetapkan untuk menyelenggarakan program dan kegiatan yang menjadi kewenangan desa. Proses Penyusunan APB Desa dimulai dengan urutan sebagai berikut:

a. Pelaksana Kegiatan menyampaian usulan anggaran kegiatan kepada Sekretaris Desa berdasarkan RKP Desa yang telah ditetapkann.

b. Sekretaris Desa menyusun rancangan Peraturan Desa tentang APB Desa (RAPB Desa) dan menyampaikan kepada Kepala Desa.

c. Kepala Desa selanjutnya menyampaikan kepada Badan Permusyawaratan Desa untuk dibahas dan disepakati bersama. Rancangan Peraturan Desa tentang APB 
Desa disepakati bersama paling lambat bulan Oktober tahun berjalan antara Kepala Desa dan BPD.

d. Rancangan Peraturan Desa tentang APB Desa yang telah disepakati bersama sebagaimana selanjutnya disampaikan oleh Kepala Desa kepada Bupati/Walikota melalui camat atau sebutan lain paling lambat 3 (tiga) hari sejak disepakati untuk dievaluasi.

e. Bupati/Walikota menetapkan hasil evaluasi Rancangan APB Desa paling lama 20 (dua puluh) hari kerja sejak diterimanya Rancangan Peraturan Desa tentang APB Desa. Dalam hal Bupati/Walikota tidak memberikan hasil evaluasi dalam batas waktu maka Peraturan Desa tersebut berlaku dengan sendirinya.Dalam hal Bupati/ Walikota menyatakan hasil evaluasi Rancangan Peraturan Desa tentang APB Desa tidak sesuai dengan kepentingan umum dan peraturan perundang-undangan yang lebih tinggi Kepala Desa melakukan penyempurnaan paling lama 7 (tujuh) hari kerja terhitung sejak diterimanya hasil evaluasi. Apabila hasil evaluasi tidak ditindaklanjuti oleh Kepala Desa dan Kepala Desa tetap menetapkan Rancangan Peraturan Desa tentang APB Desa menjadi Peraturan Desa, Bupati/Walikota membatalkan Peraturan Desa dengan Keputusan Bupati/Walikota yang sekaligus menyatakan berlakunya pagu APB Desa tahun anggaran sebelumnya.

f. Peraturan Desa tentang APB Desa ditetapkan paling lambat tanggal 31 Desember tahun anggaran berjalan.

3. Pelaksanaan

Dalam pelaksanaan keuangan desa, terdapat beberapa prinsip umum yang harus ditaati yang mencakup penerimaan dan pengeluaran. Prinsip itu diantaranya bahwa seluruh penerimaan dan pengeluaran desa dilaksanakan melalui Rekening Kas Desa. Pencairan dana dalam Rekening Kas Desa ditandatangani oleh Kepala Desa dan Bendahara Desa. Namun khusus bagi desa yang belum memiliki pelayanan perbankan di wilayahnya maka pengaturannya lebih lanjut akan ditetapkan oleh pemerintah kabupaten/kota. Dengan pengaturan tersebut, maka pembayaran kepada pihak ketiga secara normatif dilakukan melalui transfer ke rekening bank pihak ketiga.

4. Penatausahaan

Penatausahaan Keuangan Desa adalah kegiatan pencatatan yang khususnya dilakukan oleh Bendahara Desa. Bendahara Desa wajib melakukan pencatatan terhadap seluruh transaksi yang ada berupa penerimaan dan pengeluaran. Bendahara Desa melakukan pencatatan secara sistematis dan kronologis atas transaksi-transaksi keuangan yang terjadi. Penatausahaan keuangan desa yang dilakukan oleh Bendahara Desa dilakukan dengan cara sederhana, yaitu berupa pembukuan belum 
menggunakan jurnal akuntansi.

Penatausahaan baik penerimaan kas maupun pengeluaran kas, Bendahara Desa menggunakan:
a. Buku Kas Umum
b. Buku Kas Pembantu Pajak
c. Buku Bank

Bendahara Desa melakukan pencatatan atas seluruh penerimaan dan pengeluaran dalam Buku Kas Umum untuk yang bersifat tunai. Sedangkan transaksi penerimaan dan pengeluaran yang melalui bank/transfer dicatat dalam Buku Bank. Buku Kas Pembantu Pajak digunakan oleh Bendahara Desa untuk mencatat penerimaan uang yang berasal dari pungutan pajak dan mencatat pengeluaran berupa penyetoran pajak kepada kas Negara. Khusus untuk pendapatandan pembiayaan, terdapat buku pembantu berupa Buku Rincian Pendapatan dan Buku Rincian Pembiayaan.

5. Pelaporan

Dalam melaksanakan tugas, kewenangan, hak, dan kewajibannya dalam pengelolaan keuangan desa, kepala desa memiliki kewajiban untuk menyampaikan laporan. Laporan tersebut bersifat periodik semesteran dan tahunan, yang disampaikan ke Bupati/Walikota dan ada juga yang disampaikan ke BPD. Rincian laporan sebagai berikut: Laporan kepada Bupati/Walikota (melalui camat):

a. Laporan Semesteran Realiasasi Pelaksanaan APB Desa

b. Laporan Pertanggungjawaban Realisasi Pelaksanaan APB Desa kepada Bupati/ Walikota setiap akhir tahun anggaran

c. Laporan Realisasi Penggunaan Dana Desa Laporan kepada Badan Permusyawaratan Desa (BPD)

d. Laporan Keterangan Pertanggungjawaban Realisasi Pelaksanaan APB Desa terdiri dari Pendapatan, Belanja, dan Pembiayaan.

6. Pertanggungjawaban

Laporan Pertanggungjawaban Realisasi Pelaksanaan APB Desa merupakan laporan yang disampaikan secara periodik kepada BPD terhadap pelaksanaan APB Desa yang telah disepakati di awal tahun dalam bentuk Peraturan Desa.Laporan Pertanggungjawaban Realisasi Pelaksanaan APB Desa yang harus dilampiri:

a. Format Laporan Pertanggungjawaban Realisasi Pelaksanaan APB Desa Tahun Anggaran berkenaan 
b. Format Laporan Kekayaan Milik Desa per 31 Desember Tahun Anggaran berkenaan

c. Format Laporan Program Pemerintah dan Pemerintah Daerah yang Masuk ke Desa.

\section{METODE PENELITIAN}

Dalam melakukan penelitian tentang Akuntabilitas Politik Dalam Anggaran Publik (Studi Kasus: Pengelolaan Dana Dusun Membengun (GDM) di Kabupaten Bungo ini, menggunakan Metode Penelitian Deskriptif Kualitatif. Adapun alasan penelitian ini menggunakan pendekatan kualitatif adalah karena dalam penelitian ini data yang dihasilkan berupa data deskriptif yang diperoleh dari data-data berupa tulisan, katakata dan dokumen yang berasal dari sumber atau informan yang diteliti dan dapat dipercaya.

Metode kualitatif digunakan karena beberapa pertimbangan, pertama menyesuaikan metode kualitatif lebih mudah apabila berhadapan dengan kenyaataan ganda. Kedua, metode ini menyajikan secara langsung hakekat hubungan antara peneliti dan responden. Ketiga, metode ini lebih peka dan lebih dapat menyesuaikan diri dengan penajaman pengaruh bersama dan terhadap pola-pola nilai yang dihadapi (Lexy J Moleong, 2011:910).

Selanjutnya penelitian kualitatif menurut Moleong (2007:6) adalah penelitian yang bermaksud untuk memahami fenomena tentang apa yang dialami oleh subjek penelitian misalnya perilaku, persepsi, motivasi, tindakan, dll., secara holistik, dan dengan cara deskripsi dalam bentuk kata-kata dan bahasa, pada suatu konteks khusus yang alamiah dan dengan memanfaatkan berbagai metode alamiah.Deskriptif kualitatifmengemukakan bahwa metodologi kualitatif sebagai prosedur penelitian yang menghasilkan data deskriptif berupa kata-kata tertulis atau lisan dari orang-orang dan perilaku yang dapat diamati (Bogdan dan Taylor, 1975).

\section{HASIL DAN PEMBAHASAN}

\section{Adanya Kebenaran untuk Realisasi Janji Kampanye}

Bupati terpilih Kabupaten Bungo dalam upaya merealisasikan janji politiknya ketika berkampanye yaitu akan memberikan bantuan keuangan kepada dusun berjumlah Rp. 250.000.000 (dua ratus lima puluh juta) perdusun, telah menyusun sebuah keputusan melalui Peraturan Bupati Nomor 5 Tahun 2017 Tentang Pedoman dan Petunjuk Teknis Program Gerakan Dusun Membangun (GDM) Kabupaten Bungo (Hasil wawancara dengan Selcy, Kepala Seksi DPMD pada tanggal 06/06/2018 di Kantor Dinas PMD Kabupaten Bungo). Pada Perbub Nomor 5 Tahun 2017 yang telah di susun tersebut terdapat Visi dan misi GDM, yang di jelaskan pada tabel sebagai berikut : 
Tabel 1. Visi dan Misi GDM

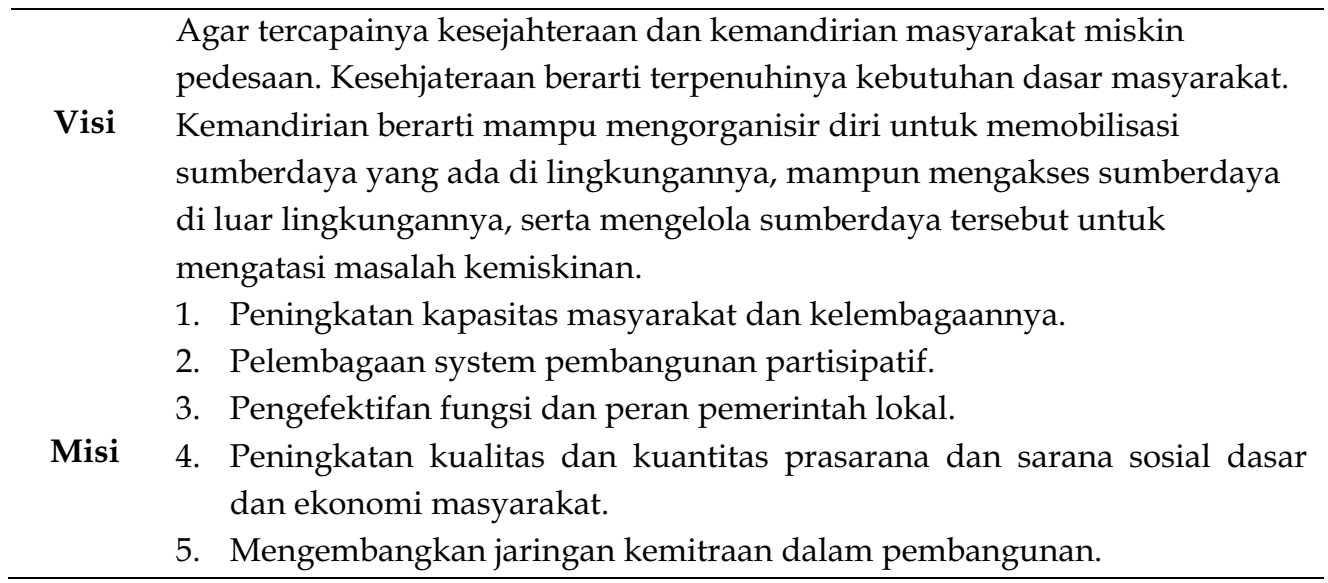

\section{Sumber: Perbub Nomor 5 Tahun 2017 Tentang Pedoman dan Petunjuk Teknis Program GDM Kabupaten Bungo}

Untuk mencapai Visi dan misi GDM strategi yang dikembangkan adalah sebagai berikut :

1. Menjadikan masyarakat miskin sebagai sasaran

2. Menguatkan system partisipatif

3. Kerjasama antar dusun

4. Pemberdayaan

Maka GDM lebih menekankan pentingnya pemberdayaan sebagai pendekatan yang di pilih, melalui GDM diharapkan masyarakat dapat turut berpartisipasi dalam strategi ini karena kuncinya adalah kesadaran masyarakat untuk ikut serta dalam pembangunan dusun (Hasil wawancara dengan Selcy, Kepala Seksi DPMD pada tanggal 06/06/2018 di Kantor Dinas PMD Kabupaten Bungo).

Adapun tujuan khususnya adalah meliputi yang dapat dijelaskan pada tabel sebagai berikut. 
Tabel 2. Tujuan Dana GDM

\begin{tabular}{|c|c|}
\hline No & Tujuan \\
\hline 1 & $\begin{array}{l}\text { Meningkatkan partisipasi seluruh masyarakat, khususnya masyarakat miskin } \\
\text { dan kelompok perempuan, dalam mengambil keputusan, perencanaan dan } \\
\text { pelaksanaan dan pemantauan pembangunan. }\end{array}$ \\
\hline 2 & $\begin{array}{l}\text { Melembagakan pengelolaan pembangunan partisipatif dengan } \\
\text { mendayagunakan sumberdaya lokal. }\end{array}$ \\
\hline 3 & $\begin{array}{l}\text { Mengembangkan kapasitas pemerintah dusun dalam menfasilitasi pengelolaan } \\
\text { pembangunan partisipatif. }\end{array}$ \\
\hline 4 & Mendorong terbentuk dan berkembangnya kerja sama antardusun. \\
\hline 5 & $\begin{array}{l}\text { Mengembangkan kerja sama antarpemangku kepentingan dalam upaya } \\
\text { penanggulangan kemiskinan perdesaan. }\end{array}$ \\
\hline
\end{tabular}

\section{Sumber: Pergub Nomor 5 Tahun 2017 Tentang Pedoman dan Petunjuk Teknis Program GDM Kabupaten Bungo}

Untuk realisasi dana GDM Tahun 2017 sebagaimana yang telah di intruksikan di dalam Perbub Nomor 5 Tahun 2017, bahwa pelaksanaan dana Gerakan Dusun Membangun (GDM) Tahun 2017 harus dilaksanakan sesuai dengan keputusan yang berlaku yaitu seperti alur keuangan pertama harus melalui Rekning Kas Umum Daerah setelah itu ke Rekening Kas Dusun, kemudian ada Tim evaluasi di kecamatan, ada tim koordinasi Kabupaten, ada supervisor atau pendamping yang diberi nama Faskab berkedudukan di kabupaten, semuanya telah dilaksanakan, dan penggunaan dana harus selaras dengan Visi misi, strategi, dan tujuan GDM (Hasil wawancara dengan Selcy, Kepala Seksi DPMD pada tanggal 06/06/2018 di Kantor Dinas PMD Kabupaten Bungo). Untuk lebih memahai terkait aturan pelaksaan dana GDM tahun 2017 dijelaskan pada tabel sebagai berikut: 
Tabel 3. Intruksi dan Aturan oleh Bupati dalam Realisasi Dana GDM

\begin{tabular}{|c|c|c|c|c|c|}
\hline No & Bagian & Pasal & Keterangan & Intruksi/aturan & Realisasi \\
\hline \multirow[t]{5}{*}{1} & Kesatu & 6 & Penyaluran & Dana GDM & Pelaksanaan GDM \\
\hline & & & Dana & disalurkan dari & Tahun 2017 telah \\
\hline & & & & rekening kas umum & dilaksanakan sesuai \\
\hline & & & & daerah ke rekening & dengan keputusan yang \\
\hline & & & & kas dusun & berlaku \\
\hline \multirow[t]{13}{*}{2} & Kedua & 7 & Tim & Camat melakukan & Pelaksanaan pembinaan \\
\hline & & & evaluasi di & tugas pembinaan & dan pengawasan camat \\
\hline & & & Kecamatan & pengawasan dusun. & fungsinya tidak terlalu \\
\hline & & & & & kritikal, karena dalam \\
\hline & & & & Pembinaan dan & pelaksanaannya camat \\
\hline & & & & pengawasan & hanya memverifikasi, \\
\hline & & & & berbentuk bantuan & ketika akan \\
\hline & & & & fasilitas dan & dilakukannya \\
\hline & & & & konsultasi. & pencairan, kemudian \\
\hline & & & & & dapat dilihat \\
\hline & & & & & pemerintah desa masih \\
\hline & & & & & kebingungan dalam \\
\hline & & & & & administrasi \\
\hline \multirow[t]{10}{*}{3} & Keempat & 9 & Faskap & Faskap & Faskab dalam tugasnya \\
\hline & & & & berkedudukan di & akan sangat kesulitan \\
\hline & & & & Kabupaten sebagai & karena jumlah SDM \\
\hline & & & & pendamping dan & faskab dengan jumlah \\
\hline & & & & supervisor. & $\begin{array}{l}\text { dusun yang ada sangat } \\
\text { tidak ideal, karena }\end{array}$ \\
\hline & & & & Faskap berhak & hanya terdiri dari 4 \\
\hline & & & & mendapat & (empat) orang: 1 orang \\
\hline & & & & honorarium & koordinator dan 3 orang \\
\hline & & & & & fasilitator untuk \\
\hline & & & & & mengurusi 141 dusun. \\
\hline
\end{tabular}

\section{Sumber: Perbub Nomor 5 Tahun 2017 Tentang Pedoman dan Petunjuk Teknis Program GDM Kabupaten Bungo}

Peraturan tersebut merupakan menjadi dasar komitmen pemerintah kabupaten dalam hal ini adalah bupati sebagai penggagas program dana GDM ini namun pertanggungjawaban dana GDM ini bukan semata-mata sebagai tanggungjawab Bupati namun ada pemerintahan dusun juga harus bertanggungjawab untuk melaksanakan peraturan yang sudah ada. 


\section{Adanya Legalitas Pertaggungjawaban Pelaksanaan Janji Kampanye}

Peraturan dan Legalitas

Kabupaten Bungo dalam pelaksanaan dana GDM telah memiliki legalitas yang mendasar melalui Perbub Nomor 5 Tahun 2017 Tentang Pedoman dan Petunjuk Teknis Program Gerakan Dusun Membangun yang di dalamnya sudah terdapat aturan pelaksanaan dana GDM dan sanksi-sanksi jika dalam pelaksanaan dana GDM tidak sesuai dengan ketentuan yang sudah atur dan bersifat legal.

Pelaksanaan dana GDM dapat dibagi menjadi dua elemen yaitu peraturanturan untuk Pemerintah Kabupaten dan Pemerintah Dusun, sebagai berikut :

1. Peraturan Pemerintah Kabupaten (DPMD)

Pemerintahan Kabupten yang menjadi penanggungjawab langsung pelaksanaan dan GDM secara politik adalah bupati. Dalam pelaksanaannya memiliki aturan dan sanksi yang harus dipatuhi, pada table sebagai berikut :

Tabel 4. Peraturan Pelaksanaan Dana GDM Pemerintah Kabupaten Menurut Perbub Nomor 5 Tahun 2017

\begin{tabular}{cll}
\hline No & \multicolumn{1}{c}{ Sanksi } & \multicolumn{1}{c}{ Sanksi Program } \\
\hline 1 & $\begin{array}{l}\text { Sanksi Program apabila dusun } \\
\text { yang bersangkutan menyalahi }\end{array}$ & Penundaan penyaluran bantuan \\
& $\begin{array}{l}\text { wewenang, penyimpangan } \\
\text { prosedur, tidak menyelesaikan }\end{array}$ & \\
& kegiatan & \\
2 & Sanksi Hukum & Hukuman sesuai dengan Undang- \\
& & Undang \\
\hline
\end{tabular}

\section{Sumber: Perbub Nomor 5 Tahun 2017 Tentang Pedoman dan Petunjuk Teknis Program GDM Kabupaten Bungo}

Sanksi yang diberikan masih belum tegas dalam upaya pencegahan, jika sanksi ini tidak tegas dan jelas akan rentan adanya peraktik penyimpangan dalam penggunaan dana GDM. Begitu juga dengan sanksi hukum yang tertulis di dalam Perbub masih tidak jelas, sanksi dikaitkan dengan Undang-Undang yang mana yang menjadi dasar untuk memberikan sanksi dan seperti apa sanksi yang di berikan. hal ini akan menyebabkan kebigungan dalam penindakan pemberian sanksi jika ada penyimpangan pelaksanaan dana GDM. 
2. Peraturan Khusus Pemerintahan Tingkat Dusun (Otonomi Desa)

Pada pelaksanaan tingkat dusun yang menjadi penanggugjawab secara politik adalah Rio (kepala desa). Berdasarkan Perbub Nomor 5 Tahun 2017 Tentang Pedoman dan Petunjuk Teknis Program Gerakan Dusun Membangun (GDM) Kabupaten Bungo memiliki ketentuan sebagai berikut berikut :

Tabel 5. Peraturan Pelaksanaan Dana GDM Pemerintahan Dusun Berdasarkan Perbub Nomor 5 Tahun 2017

\begin{tabular}{|c|c|c|}
\hline No & Aturan & Keterangan \\
\hline 1 & $\begin{array}{l}\text { Peran } \\
\text { Pemerintahan } \\
\text { Dusun }\end{array}$ & $\begin{array}{l}\text { Pemerintah Dusun sebagai penerima GDM yang } \\
\text { melaksanakan perencanaan sebagian dari } \\
\text { pelaksanaan, pemerintah dusun wajib melibatkan } \\
\text { masyarakat dusun, }\end{array}$ \\
\hline 2 & $\begin{array}{l}\text { Partisipasi } \\
\text { Masyarakat }\end{array}$ & $\begin{array}{l}\text { Masyarakat dusun berhak berpartisipasi dalam } \\
\text { perencanaan, sebagian dari pelaksanaan dan } \\
\text { pengawas kegiatan GDM. }\end{array}$ \\
\hline 3 & Jenis kegiatan & $\begin{array}{l}\text { Kegiatan yang dapat dibiayai melalui GDM adalah } \\
\text { sebagai berikut berdasarkan Perbub Nomor } 5 \text { Tahun } \\
2017 \text { adalah : } \\
\text { 1. Pembangunan pelayanan dasar } \\
\text { 2. Pembangunan sarana dan prasarana dusun: } \\
\text { 3. Pembangunan ekonomi dusun } \\
\text { 4. 4. Pemberdayaan dusun }\end{array}$ \\
\hline
\end{tabular}

\section{Sumber: Perbub Nomor 5 Tahun 2017 Tentang Pedoman dan Petunjuk Teknis Program GDM Kabupaten Bungo}

Intruksi dan Peraturan yang dapat dilihat pada tabel di atas yang diberikan kepada dusun sangat banyak namun tidak seberapa yang dapat terealisasi, hal ini disebabkan karena tidak seimbangnya pendanaan yang diberikan dengan harapan pembangunan yang begitu banyak, Maka untuk percepatan pembangunan memberikan uang kepada dusun belum menjadi solusi yang baik untuk percepatan pembangunan, apa yang tertulis didalam Perbub terkait dana GDM masih terkesan sekedar teknis belum mengarah kepada hasil (output) dari kebijakan yang diberikan kepada dusun.

Kemudian peraturan dalam alur pelaksanaan dana GDM dibagi menjadi empat tahap yaitu perencanaan, pelaksanaan, pertanggungjawaban dan terakhir evaluasi, yang dapat dilihat pada gambar sebagai berikut: 


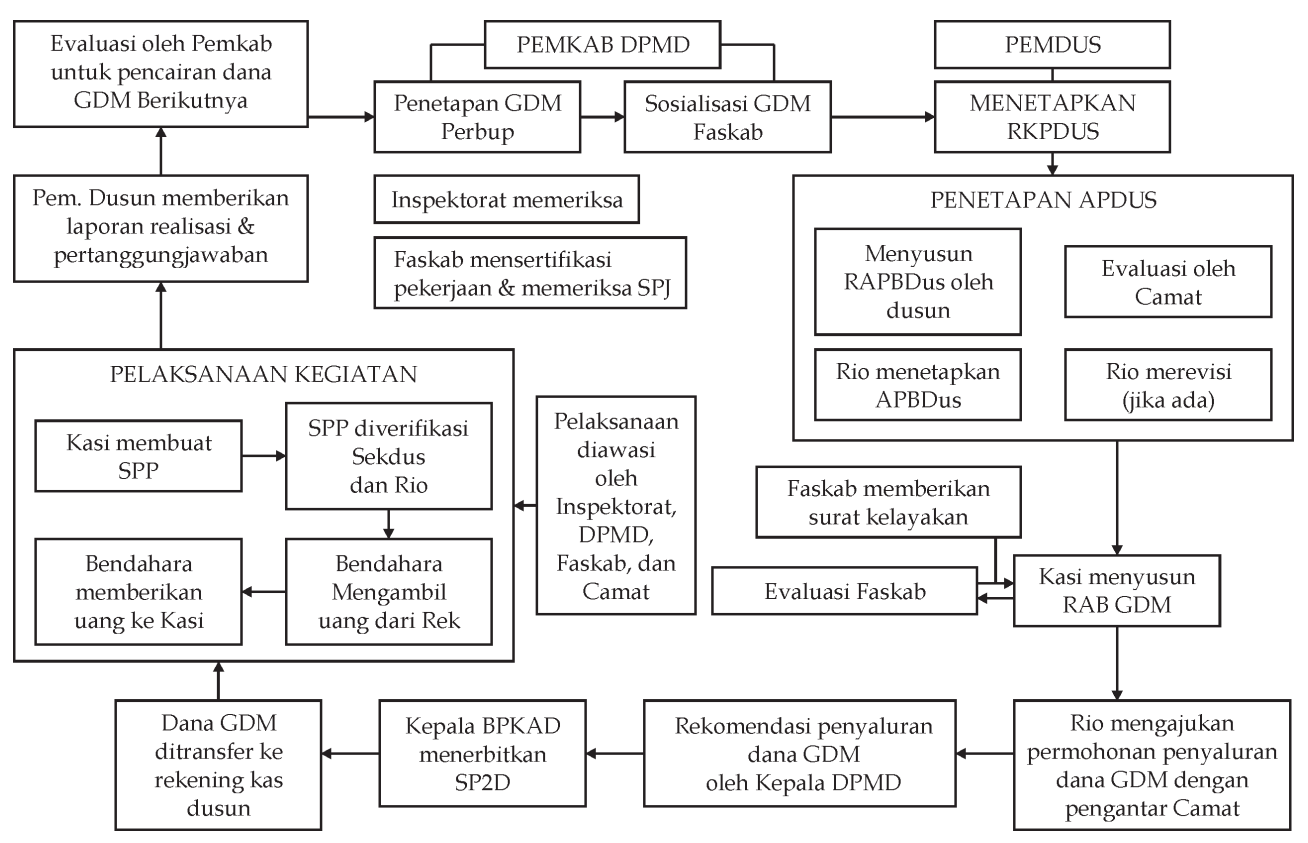

Gambar 2. Peraturan Alur Pelaksaan Dana GDM Berdasarkan Perbub Nomor 5 Tahun 2017

Gambar di atas merupakan alur pelaksanaan dana GDM menurut Perbub Nomor 5 Tahun 2017 Tentang Pedoman Petunjuk Teknis Program GDM, inti dari proses ini sebenarnya hanya terbagi 4 (empat) prinsip yaitu perencanaan Anggaran, Pelaksanaan anggaran, pertanggungjawaban anggaran atau pelaporan, dan yang terakhir adalah evaluasi. Didalam gambar terdapat dua warana yaitu warna kuning dan biru, kolom yang berwarna biru artinya kegiatan yang berada pada sektor pemerintahan dusun sedangkan yang kenuning merupakan sektor pemerintah kabupaten.

Warna tersebut menjelaskan pada awalnya pemerintah kabupaten atau bupati menyusun kebijakan dana GDM kemudian dilanjutkan dengan sosialisasi kepada dusun oleh faskab, kemudian dusun menyusun dokumen perencanaan yang kemudian di evaluasi oleh camat, kemudian menyusun RAB pembangunan yang di verifikasi oleh faskab, setelah di verifikasi baru Rio membuat dokumen permohonan penyaluran dana GDM.

Bersamaan dengan pengantar camat baru kemudian DPMD mengeluarkan surat rekomendasi yang akan di berikan kepada BPKAD menerbitkan surat SP2D dana Dana GDM bisa di transfer ke rekening dusun, stelah itu dana GDM direalisasikan oleh Kasi (kepala seksi) dengan membuat SPP dan di verifikasi oleh Rio setelah di verifikasi uang dapat di ambil kepada bendahara. Setelah dana direalisasikan pemerintahan dusun membuat dokumen pelaporan dan pertanggungjawaban. Faskab memverifikasi pekerjaan dan dokumen pertanggungjawaban kemudian terakhir dilakukan evaluasi oleh pemkab untuk pencairan tahap berikutnya. 
Sanksi

Selain peraturan dalam pelaksanaan dana GDM di tingkat desa yang terpenting juga adalah sanksi. Sanksi adalah salah satu bentuk pemberlakuan kondisi dikarenakan adanya pelanggaran atas peraturan dan tata cara yang telah ditetapkan di dalam pelaksanaan dana GDM dan sanksi bertujuan untuk menumbuhkan rasa tanggungjawab kepada pihak pelaksana dana GDM. Berdasarkan Perbub Nomor 5 tahun 2017 Sanksi yang dapat berupa, yaitu sebagai berikut :

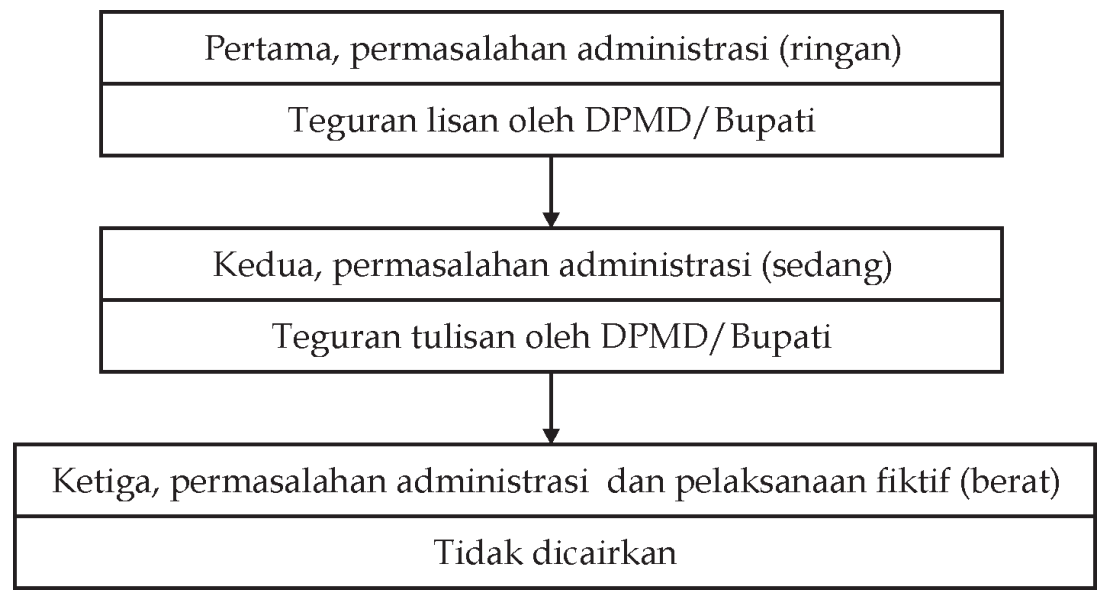

Gambar 3. Alur Pemberian Sanksi

Dalam pelaksanaannya Pemerintah Kabupaten Bungo dalam memberikan sanksi yaitu kepada Dusun Sinamat Ulu karena dalam Dusun Sinamat Ulu tidak memberikan laporan realisasi kegiatan dan laporan pertanggungjawaban untuk pelaksanaan dana GDM Tahap I. Maka Pemerintahan Dusun Sinamat Ulu mendapat saksi yaitu tidak dapat mencairkan dana GDM Tahap II (Hasil wawancara dengan Selcy, Kepala Seksi DPMD pada tanggal 06/06/2018 di Kantor Dinas PMD Kabupaten Bungo).

\section{Adanya Komitmen Bupati dalam Pelaksanaan Dana GDM}

Bupati Bungo terpilih menunjukan keseriusan dan komitmennya dalam merealisasikan janji politiknya yaitu pelaksanaann dana GDM melalui Perbub Nomor 5 Tahun 2017 yaitu tentang pedoman dan petunjuk teknis pelaksanaan dana GDM yang di dalamnya mengatur tentang pelaksaan dana GDM, system, beserta sanksi pertanggungjawababnya. Terealisasinya Dana GDM sesuai dengan pedoman dan petunjuk teknis pelaksanaan dana GDM yaitu dapat digambarkan pada tabel sebagai berikut: 
Tabel 6. Komitmen Bupati Bungo Terpilih dalam Merealisasikan Janji Politik

\begin{tabular}{clc}
\hline No & \multicolumn{1}{c}{ Komitmen } & Pasal \\
\hline 1 & $\begin{array}{l}\text { Dana GDM harus disalurkan dari rek kas umum } \\
\text { daerah ke kas dusun }\end{array}$ & Pasal 6 \\
2 & $\begin{array}{l}\text { Membentuk tim evaluasi di kecamatan dan harus } \\
\text { mengefektifkan fungsinya untuk membina dusun } \\
\text { dalam pelaksanaan dana GDM }\end{array}$ & Pasal 7 \\
4 & $\begin{array}{l}\text { Pembentukan faskab sebagai supervisor pelaksanaan } \\
\text { GDM }\end{array}$ & Pasal 9 \\
5 & $\begin{array}{l}\text { GDM harus dikelola berdasarkan asas transparan, } \\
\text { akuntabel, partisipatif, serta tertib anggaran. } \\
\text { Bupati harus ikut serta secara aktif melakukan } \\
\text { pembinaan dan pengawasan }\end{array}$ & Pasal 10 \\
\hline
\end{tabular}

\section{Sumber: Perbub Nomor 5 Tahun 2017 Tentang Pedoman dan PetunjukTeknis Program GDM Kabupaten Bungo}

Komitmen bupati bungo dalam merealisasikan janji kampanye untuk penyaluran pendanaan dusun sebelumnya harus memenuhi syarat-syarat dokumen berupa (Hasil wawancara dengan Selcy, Kepala Seksi DPMD pada tanggal 06/06/2018 di Kantor Dinas PMD Kabupaten Bungo) :

1. RPJMDus

2. RKPDus

3. APBDus

4. RAB

5. Surat permohonan pencairan

Namun terdapat situasi berbeda yang terjadi dengan Dusun Sinamat Ulu yang sama sekali tidak memiliki dokumen RPJMDus, RKPDus, APBDus, RAB (Hasil wawancara dengan Rozi Kabag PMD pada tanggal 09/06/2018 di Kantor Kecamatan Bathin III Ulu). Begitu juga penulis berupaya mendapatkan data kepada Pemerintahan Dusun Sinamat Ulu namun Rio dan perangkat dusun menolak untuk di temui, maka penulis melanjutkan untuk mendapatkan data kepada Inspektorat dan DPMD untuk menganalisa bahwa dokumen benar-benar tidak ada (Hasil wawancara dengan sofian Kabag Pemdus pada tanggal 10/06/2018 di Kantor Inspektorat Kabupaten Bungo dan Sam Koordinator Faskab GDM 11/06/2018 di kantor DPMD Kabupaten Bungo).

Meskipun begitu dusun sinamat ulu tetap mendapatkan transfer dana GDM Tahap I oleh Pemerintah Kabupaten, hal ini karena Program GDM masih tahap awal yang harus di uji cobakan, tika tidak dilaksakan lalu kapan akan bisa dilaksanakan (Hasil wawancara 
dengan Selcy, Kepala Seksi DPMD pada tanggal 06/06/2018 di Kantor Dinas PMD Kabupaten Bungo).

\section{Adanya Kebenaran dalam Pelaksanaan Dana GDM di Dusun}

Pelaksanaan dana GDM di dusun seiring dengan disahkannya Perbub nomor 5 tahun 2017 tentang pedoman dan petunjuk teknis program GDM telah benar-benar dilaksanakan berdasarkan skema alur kegiatan yang dapat dilihat pada gambar sebagai berikut :

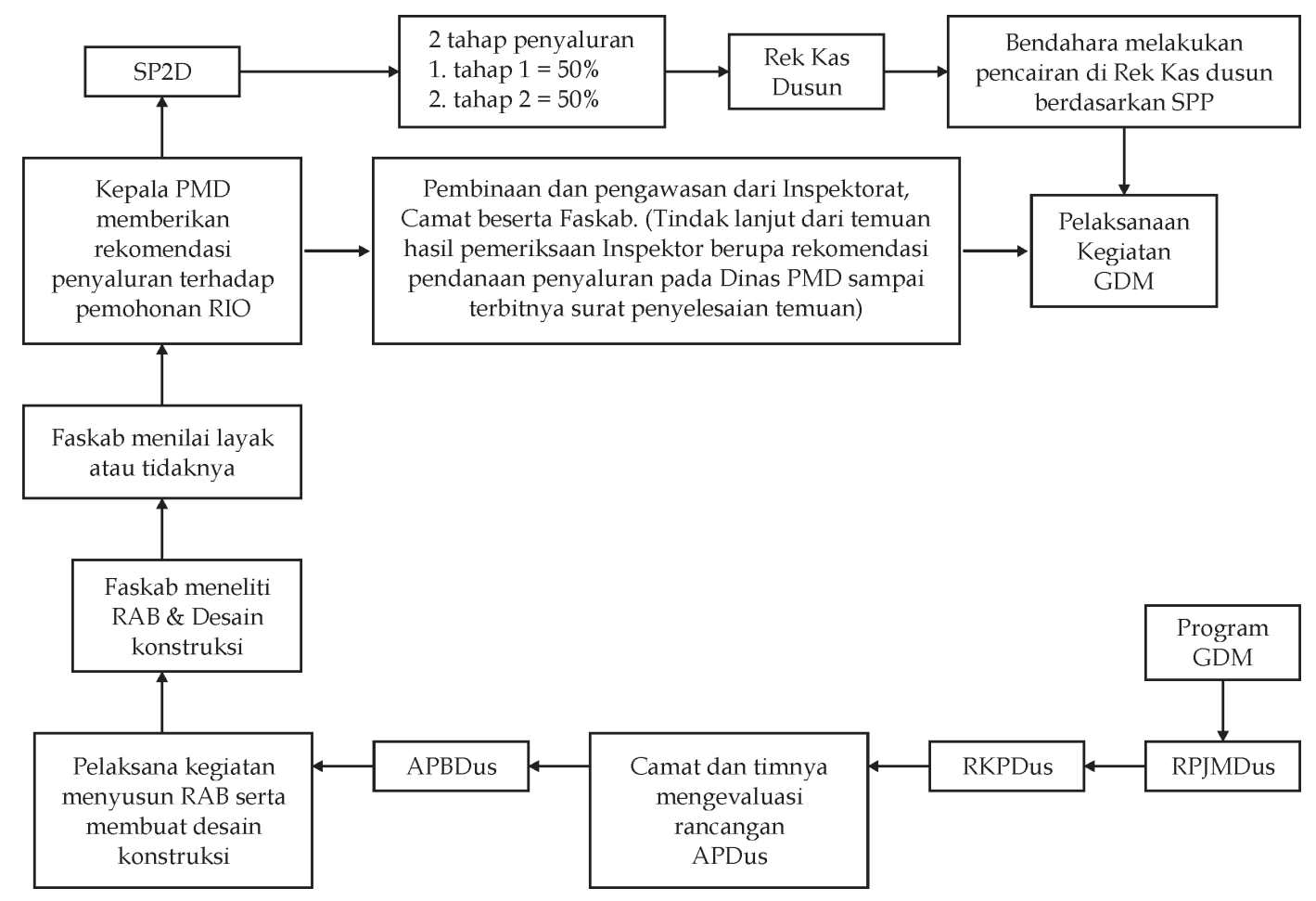

Gambar 4. Skema Alur Kegiatan Pelaksanaan Dana GDM

Gambar di atas merupakan skema dan syarat pencairan Tahap I dana GDM. Pelaksanaan harus berasaskan kepada perinsip tertib, disiplin anggaran, transparansi, akuntabel dan, pertisipatif. pada awalnya adalah mempersiapkan dokumen perencaan RPJMDus, RKPDus, dan APBDus kemudian penyusunan desain kontruksi (RAB) yang dilakukan secara partisipatif dengan sekema sebagai berikut : 


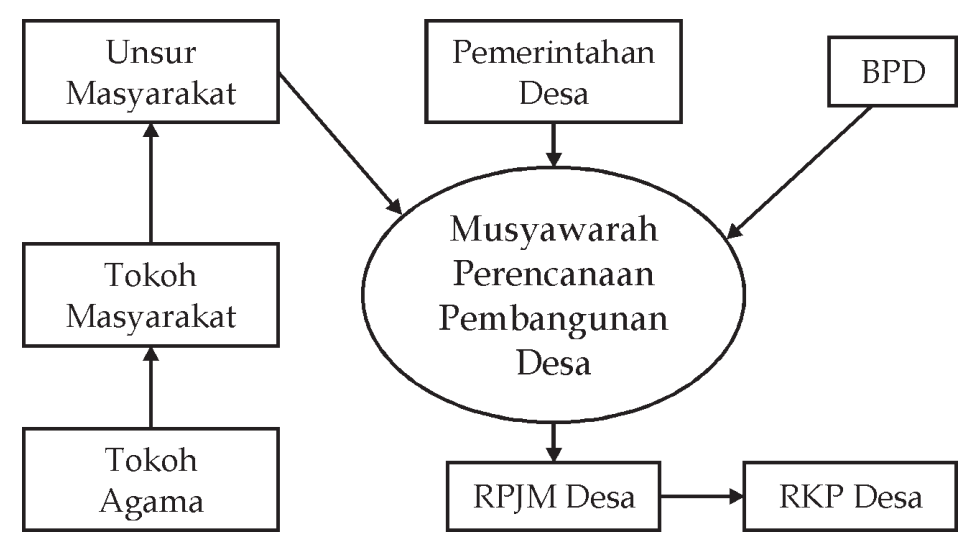

Gambar 5. Skema Penyusunan Perencanaan yang Partisipatif

Kemudian dokumen perencanaan dan penganggaran di verifikasi oleh faskab, kemudian baru DPMD menerbitkan SP2D untuk pencairan, untuk pencairan dilakukan transfer dari rek kabupaten ke rekening dusun. Yang Pelaksanaan dana GDM harus berdasarkan asas transparansi, akuntabel, partisipatif, dan dilakukan dengan tertib dan disiplin anggaran (Hasil wawancara dengan Selcy, Kepala Seksi DPMD pada tanggal 06/06/2018 di Kantor Dinas PMD Kabupaten Bungo).

\section{Adanya Kebenaran dalam Pelaksanaan Dana GDM di Dusun Lubuk Beringin, Timbolasi dan Sinamat Ulu}

Pemerintahan Lubuk Beringin dalam realisasi anggaran dana GDM Tahap 1 Tahun 2017 telah diterima dengan jumlah Rp. 75.000 .000 dan digunakan dengan tertib anggaran yang di perincikan penggunaannya seperti di atas sehingga uang keluar dengan jumlah Rp. 72.215.000 dan uang yang tersisa pada saldo berjumlah Rp. 9.159.649. Namun Dusun Lubuk Beringin mengaku sangat kesulitan dalam pembuatan dokumen-dokumen yang diharuskan oleh pemerintah kabupaten terutama pembuatan desaign RAB sehingga harus membayar jasa pembuatannya di luar pemerintahan dusun, kemudian dokumen laporan pertanggungjawaban yang begitu banyak dokumen-dokumen yang harus di serahkan kepada pemerintahan kabupaten yang dirasa tidak akan juga di baca oleh pemerintah kabupaten, karena ada sangat banyak dokumen yang masuk dari 141 dusun se-Kabupaten Bungo.

Dusun Timbolasi sama halnya dengan Dusun Lubuk Beringin dalam pelaksanaan dana GDM penyusunan perencanan telah dilakukan dengan partisipatif yaitu melibatkan perangkat dusun, tokoh masyarakat, beserta bersama masyarakat dusun itu sendiri. (Hasil wawancara dengan Selcy, Kepala Seksi DPMD pada tanggal 06/06/2018 di Kantor Dinas PMD Kabupaten Bungo). 
Pemerintahan Dusun Timbolasi dalam realisasi anggaran dana GDM Tahap 1 Tahun 2017 telah diterima dengan jumlah Rp. 75.000.000 dan digunakan dengan tertib anggaran yang di perincikan penggunaannya seperti di atas sehingga uang keluar dengan jumlah Rp. 74.335.000 dan uang yang tersisa pada saldo berjumlah Rp. 665.000. Namun untuk rincian penerimaan pajak tidak dijabarkan di dalam penerimaan. Kemudian sama halnya dengan dusun lubuk beringin mengeluhkan sulitnya system yang sekarang menyebabkan pemerintahan dusun lebih sibuk mengurusi dokumen dari pada hal lain.

Sedangkan Dusun Sinamat Ulu, memiliki situasi yang berbeda dibandingkan dengan Dusun Lubuk Beringin dan Timbolasi dari segi jarak tempuh, geografis, dan akses jalan begitu juga dalam pelaksanaan dana GDM Dusun Sinamat Ulu tidak melakukan penyusunan dokumen perencanaan sama sekali. Namun pemerintah kabupaten tetap memberikan dana GDM tahap I (satu) karena diberikan dispensasi. Kenapa bisa seperti itu karena dana GDM baru percobaan tahap awal, namun Dusun Sinamat Ulu walaupun telah di berikan dispensasi namun tetap tidak penyusunan dokumen perancanaan.

bahkan realisasi anggaran tidak jelas di gunakan untuk pembangunan apa, bahkan sampai pada tahap pelaporan pertanggungjawaban masih tidak memberikan dokumen pertanggungjawaban sehingga Dusun Sinamat Ulu mendapat sanksi tidak dapat mencairkan untuk tahap II, dan jika masih tidak ada kejelasan akan di proses secara hukum (Hasil wawancara dengan Selcy, Kepala Seksi DPMD pada tanggal 06/06/2018 di Kantor Dinas PMD Kabupaten Bungo).

\section{Tabel 7. Komparasi Kebenaran Pelaksanaan Dana GDM di Dusun Lubuk Beringin,} Timbolasi dan Sinamat Ulu

\begin{tabular}{clccc}
\hline No & \multicolumn{1}{c}{$\begin{array}{c}\text { Kebenaran dalam } \\
\text { Pelakasanaan }\end{array}$} & $\begin{array}{c}\text { Dusun } \\
\text { Lubuk } \\
\text { Beringin }\end{array}$ & $\begin{array}{c}\text { Dusun } \\
\text { Timbolasi }\end{array}$ & $\begin{array}{c}\text { Dusun } \\
\text { Sinamat } \\
\text { Ulu }\end{array}$ \\
\hline 1 & $\begin{array}{l}\text { Adanya dokumen perencanaan } \\
\text { (RPJMD, RAB) }\end{array}$ & Ada & Ada & Tidak ada \\
2 & $\begin{array}{l}\text { Adanya dokumen laporan } \\
\text { realisasi anggaran (LPJ) }\end{array}$ & Ada & Ada & Tidak ada \\
\hline
\end{tabular}

Dari analisa tersebut dalam pelaksanaan Dana GDM pada Pemerintah Dusun Lubuk Beringin dan Timbolasi telah benar-benar dilakukan sesuai dengan intruksi bupati yang dijabarkan pada Perbub Nomor 5 Tahun 2017. Namun untuk Dusun Sinamat Ulu masih belum benar-benar dilakukan karena masih terdapat beberapa kendala yaitu yang berada di Dusun Sinamat Ulu khusunya yang di sebabkan karena keterbatasan SDM, akses yang sulit, jumlah desa yang banyak, prosedur yang sulit, maka dari itu perlu adanya kajian lebih lanjut terkait pelaksanaan dana GDM ini. 


\section{Adanya Transparansi Penggunaan Dana GDM di Dusun Lubuk Beringin, Timbolasi dan Sinamat Ulu}

Jika dibandingkan bentuk transparansi yang dilakukan oleh Dusun Sinamat Ulu dan Timbolasi pelaksanaannya sama-sama telah berupaya menunjukan transparansi namun hanya sebatas mengikuti intruksi didalam Perbub Nomor 5 Tahun 2017, dan transparansi yang ditunjukan hanya jumlah total pembiayaan atau belum dirincikan secara mendetail penggunaan dan harga material apa saja, bagi masyarakat melihat ini hanya sebatas formalitas ksrena sulit untuk memahami jika hanya total keseluruhan yang ditampilkan pada sepanduk pertanggungjawaban tersebut. Jika dibandikan antara Dusun Lubuk Beringin, Timbolasi dan Sinamat Ulu. Sianamat Ulu belum samasekali menunjukan transparansinya dalam penggunaan dana GDM karena tidak ada data yang mendukung untuk menjukan Dusun Sinamat Ulu transparansi atau tidak bahkan perangkat desa di dusun tersebut menolak untuk di wawancarai. Sebaiknya isi dari spanduk yang dipajang sesuai dengan RAB agar lebih rinci dan jelas, seperti pada tabel sebagai berikut: 
Tabel 8. Laporan Pertanggungjawaban Realisasi GDM

\begin{tabular}{|c|c|c|c|c|}
\hline No & Uraian & $\begin{array}{l}\text { Penerimaan } \\
\quad(\mathrm{Rp})\end{array}$ & $\begin{array}{l}\text { Pengeluaran } \\
\text { (Rp) }\end{array}$ & Saldo \\
\hline 1 & $\begin{array}{l}\text { Terima dana transfer dari } \\
\text { SP2D }\end{array}$ & 75.000 .000 & & 75.000 .000 \\
\hline \multirow[t]{3}{*}{2} & $\begin{array}{l}\text { Dibayarkan kepada sumber } \\
\text { makmur pembelian semen } \\
25 \text { sak }\end{array}$ & & 9.019 .000 & 65.981 .000 \\
\hline & Terima PPN DN & 901.900 & & 66.882 .900 \\
\hline & Terima PPH Pasal 22 & 121.757 & & 67.004 .657 \\
\hline 3 & PembayaranTukang & & 10.358 .000 & 56.646 .657 \\
\hline \multirow[t]{3}{*}{4} & Pembelian keramik & & 21.605 .000 & 35.041 .657 \\
\hline & Terima PPN DN & 2.160 .500 & & 37.202 .157 \\
\hline & Terima PPH Pasal 22 & 291.668 & & 37.493 .824 \\
\hline \multirow[t]{2}{*}{5} & Belanjapasir dan kerikil & & 4.343 .000 & 33.150 .824 \\
\hline & Pajak Galian C & 220.000 & & 33.370 .824 \\
\hline 6 & $\begin{array}{l}\text { Pembelian perlenkapan dan } \\
\text { bahan baku }\end{array}$ & & 1.324 .000 & 32.046 .824 \\
\hline \multirow[t]{3}{*}{7} & $\begin{array}{l}\text { Pembelian kursi, meja } \\
\text { lemari, papan tulis, dan } \\
\text { pembatas lokal }\end{array}$ & & 20.000 .000 & 12.046 .824 \\
\hline & Terima PPN DN & 2.000 .000 & & 14.046 .824 \\
\hline & Terima PPH Pasal 22 & 270.000 & & 14.326 .824 \\
\hline 8 & $\begin{array}{l}\text { Pembelian spanduk papan } \\
\text { kegiatan }\end{array}$ & & 251.000 & 14.065 .824 \\
\hline \multirow[t]{3}{*}{9} & $\begin{array}{l}\text { Pembuatan dana prasasti } \\
\text { dana GDM }\end{array}$ & & 1.115 .000 & 12.950 .824 \\
\hline & Terima PPN DN & 111.500 & & 13.062 .824 \\
\hline & Terima PPH Pasal 22 & 15.053 & & 13.077.377 \\
\hline 10 & Pembuatan desaign RAB & & 1.500 .000 & 11.577.377 \\
\hline \multirow[t]{4}{*}{11} & Kepada saudara anwar & & 2.700 .000 & 8.877.377 \\
\hline & Terima PPN DN & 245.455 & & 9.122 .831 \\
\hline & Terima PPH Pasal 22 & 36.818 & & 9.159 .649 \\
\hline & JUMLAH & 81.374 .649 & 72.215 .000 & 9.159 .649 \\
\hline
\end{tabular}

Sumber: Laporan Pertanggungjawaban Dana GDM Tahap I Tahun 2017 Pembangunan Madrasah

Agar memudahkan masyarakat untuk memahami jumlah total yang di tampilkan dan agar lebih jelas sebaiknya ditampilkan beserta rincian seperti pada tabel di atas yang bersumber dari RAB masing-masing dusun. 
Tabel 9. Komparasi Adanya Trasnparansi di Dusun Lubuk Beringin, Timbolasi dan Sinamat Ulu

\begin{tabular}{ccccc}
\hline No & $\begin{array}{c}\text { Adanya Transparansi dalam } \\
\text { Perencanaan Dana GDM }\end{array}$ & $\begin{array}{c}\text { Dusun Lubuk } \\
\text { Beringin }\end{array}$ & $\begin{array}{c}\text { Dusun } \\
\text { Timbolasi }\end{array}$ & $\begin{array}{c}\text { Dusun } \\
\text { Sinamat } \\
\text { Ulu }\end{array}$ \\
\hline 1 & $\begin{array}{l}\text { Meberikan Informasi penggunaan } \\
\text { dana GDM kepada publik }\end{array}$ & Ada & Ada & Tidak ada \\
\hline
\end{tabular}

Dari analisa tersebut dalam pelaksanaan Dana GDM pada Pemerintah Dusun Lubuk Beringin dan Timbolasi telah transparansi namun sebaiknya dalam memberikan papan informasi harus ditampilkan dengan rinciannya sehingga masyarakat mendapat informasi yang lebih jelas. Sedangkan Dusun Sinamat Ulu belum transparan.

\section{Adanya Partisipatif dalam Perencanaan Dana GDM di Dusun Lubuk Beringin, Timbolasi dan Sinamat Ulu}

Dusun Lubuk Beringin dalam pelaksanaan penyusunan dokumen perencanaan telah dilakukan dengan partisipatif yaitu melibatkan seluruh stakeholder yang ada di dusun (Hasil wawancara dengan Selcy, Kepala Seksi DPMD pada tanggal 06/06/2018 di Kantor Dinas PMD Kabupaten Bungo).

Tabel 10. Partisipasi dalam Rapat Penyusunan RPJMDus

\begin{tabular}{cll}
\hline No & \multicolumn{1}{c}{ Nama } & \multicolumn{1}{c}{ Jabatan } \\
\hline 1 & Muhammad Solihin & Sebagai RIO/Kepala Desa \\
2 & Hadirin & Sebagai Ketua BPD \\
3 & Aljupri & Sebagai Ketua RT \\
4 & Hadari & Sebagai Ketua RT \\
5 & Seholit & Sebagai Kepala Kampung \\
6 & Mukhlis & Sebagai Kepala Kampung \\
7 & Sadi & Sebagai Perwakilan Tokoh Masyarakat \\
\hline
\end{tabular}

Sumber: RPJMdus Lubuk Beringin Tahun 2014-2019

Kemudian jika dibandingkan antara Dusun Lubuk beringin dan Dusun Timbolasi. Dusun Timbolasi dalam pelaksanaan dana GDM penyusunan perencanan telah dilakukan dengan partisipatif yaitu melibatkan perangkat dusun, tokoh masyarakat, beserta bersama masyarakat dusun itu sendiri. (Hasil wawancara dengan Selcy, Kepala Seksi DPMD pada tanggal 06/06/2018 di Kantor Dinas PMD Kabupaten Bungo). 
Stakeholder yang Berpartisipasi pada musyawarah penyusunan perancanaan, sebagai berikut:

Tabel 11. Partisipasi Anggota dalam Rapat Penyusunan RPJMDus

\begin{tabular}{ccc}
\hline No & Nama & Jabatan \\
\hline 1 & Junit & Sebagai Rio/Kepala Desa \\
2 & Muzir & Sebagai Ketua BPD \\
3 & Zainubi & Sebagai Sekertaris Dusun \\
4 & Kaidir & Sebagai Ketua RT \\
5 & Hardi & Sebagai Kepala Kampunng \\
6 & juanda & Sebagai Kepala kampung \\
7 & saleh & Sebagai Tokoh masyarakat \\
\hline
\end{tabular}

Sumber: RPJMDus Timbolasi Tahun 2014-2019

Sedangkan Dusun Sinamat Ulu, memiliki situasi yang berbeda dibandingkan dengan Dusun Lubuk Beringin dan Timbolasi dari segi jarak tempuh, geografis, dan akses jalan begitu juga dalam pelaksanaan dana GDM Dusun Sinamat Ulu tidak melakukan penyusunan dokumen perencanaan sama sekali tapi pemerintah kabupaten tetap memberikan dana GDM tahap I (satu) karena diberikan dispensasi. Kenapa bisa seperti itu karena dana GDM baru percobaan tahap awal, namun Dusun Sinamat Ulu walaupun telah di berikan dispensasi namun tetap tidak penyusunan dokumen perancanaan.

Tabel 12. Komparasi Adanya Perencanaan yang Partisipatif di Dusun Lubuk Beringin, Timbolasi dan Sinamat Ulu

\begin{tabular}{clccc}
\hline No & \multicolumn{1}{c}{$\begin{array}{c}\text { Adanya Partisipatif dalam } \\
\text { Perencanaan Dana GDM }\end{array}$} & $\begin{array}{c}\text { Dusun } \\
\text { Lubuk } \\
\text { Beringin }\end{array}$ & $\begin{array}{c}\text { Dusun } \\
\text { Timbolasi }\end{array}$ & $\begin{array}{c}\text { Dusun } \\
\text { Sinamat } \\
\text { Ulu }\end{array}$ \\
\hline 1 & $\begin{array}{l}\text { Melakukan penyusunan dokumen } \\
\text { perencanaan (RPJMDus, RKPdus, } \\
\text { RAB) }\end{array}$ & Ada & Ada & Tidak ada \\
2 & $\begin{array}{l}\text { Melibatkan seluruh stakeholder di } \\
\text { dusun dalam penyususnan } \\
\text { dokumen perencanaan }\end{array}$ & Ada & Ada & Tidak ada \\
\hline
\end{tabular}

Dari analisa tersebut Dusun Lubuk Beringin dan Timbolasi telah melakukan penyusunan dokumen perencanaan dengan partisipati, namun berbeda dengan halnya Dusun Sinamat Ulu tidak melakukan penyusunan dokumen perencanaan samasekali. 
Namun dalam penyusunan dokumen perancanaan ini dilakukan tanpa pendampingan dari kecamatan maupun dari kabupaten hal ini dapat menyebabkan kesulitan pemerintah dusun dalam menyususn dokumen perencanaan karena keterbatasan SDM dan sulitnya prosedur pembuatan dokumen perencanaan harus dilakukan oleh ahli. Sebaiknya dilakukan pendampingan agar dokumen yang di hasilkan sesuai dengan setandar harapan kabupaten, sehingga tidak terlalu banyak diakhir verifikasi dokumen perencanaan.

\section{Adanya kebenaran dalam pelaporan pertanggungjawaban Dana GDM di Dusun Lubuk Beringin, Timbolasi dan Sinamat Ulu}

Dalam melaksanakan tugas, kewenangan, hak, dan kewajibannya pelaksanaan dan GDM, pemerintahan dusun memiliki kewajiban untuk menyampaikan laporan pertanggungjawaban yang disampaikan ke Bupati melalui Camat dan Faskab/DPMD. Dengan alur proses sebagai berikut:

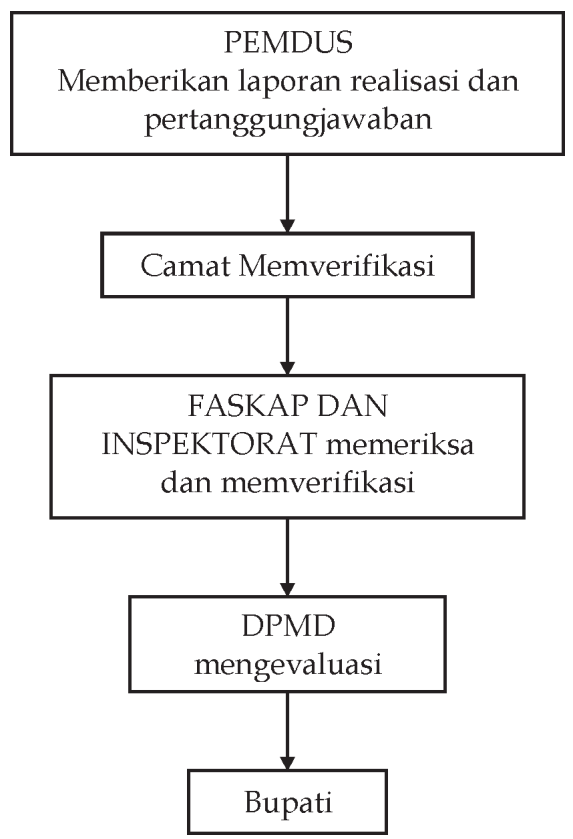

Gambar 6. Alur Pelaporan Realisasi dan Pertanggungjawaban

Dusun Lubuk beringin dan Dusun timbolasi dalam pelaporan pertanggungjawaban telah dilaksanakan. Dusun Lubuk Beringin dalam menggunakan dana GDM Tahap I (satu) adalah untuk renovasi pembangunan Sekolah Madrasah dengan rincian realisasi anggaran berdasarkan Laporan Pertanggung Jawaban (LPJ) sebagai berikut: 
Tabel 13. Pelaksanaan Dana GDM Tahap I Tahun 2017 oleh Dusun Lubuk Beringin

\begin{tabular}{|c|c|c|c|c|}
\hline No & Uraian & $\begin{array}{l}\text { Penerimaan } \\
\text { (Rp) }\end{array}$ & $\begin{array}{l}\text { Pengeluaran } \\
\text { (Rp) }\end{array}$ & Saldo \\
\hline 1 & Terima dana transfer dari SP2D & 75.000 .000 & & 75.000 .000 \\
\hline \multirow[t]{3}{*}{2} & $\begin{array}{l}\text { Dibayarkan kepada sumber } \\
\text { makmur pembelian semen } 25 \text { sak }\end{array}$ & & 9.019 .000 & 65.981 .000 \\
\hline & Terima PPN DN & 901.900 & & 66.882 .900 \\
\hline & Terima PPH Pasal 22 & 121.757 & & 67.004 .657 \\
\hline 3 & PembayaranTukang & & 10.358 .000 & 56.646 .657 \\
\hline \multirow[t]{3}{*}{4} & Pembelian keramik & & 21.605 .000 & 35.041 .657 \\
\hline & Terima PPN DN & 2.160 .500 & & 37.202 .157 \\
\hline & Terima PPH Pasal 22 & 291.668 & & 37.493 .824 \\
\hline \multirow[t]{2}{*}{5} & Belanja pasir dan kerikil & & 4.343 .000 & 33.150 .824 \\
\hline & Pajak Galian C & 220.000 & & 33.370 .824 \\
\hline 6 & $\begin{array}{l}\text { Pembelian roli, ember cor, skop, } \\
\text { centong untuk sendok semen, } \\
\text { cangkul, benang dan selang air. }\end{array}$ & & 1.324 .000 & 32.046 .824 \\
\hline \multirow[t]{3}{*}{7} & $\begin{array}{l}\text { Pembelian kursi, meja lemari, } \\
\text { papan tulis, dan pembatas lokal }\end{array}$ & & 20.000 .000 & 12.046 .824 \\
\hline & Terima PPN DN & 2.000 .000 & & 14.046 .824 \\
\hline & Terima PPH Pasal 22 & 270.000 & & 14.326 .824 \\
\hline 8 & $\begin{array}{l}\text { Pembelian spanduk papan } \\
\text { kegiatan }\end{array}$ & & 251.000 & 14.065 .824 \\
\hline \multirow[t]{3}{*}{9} & $\begin{array}{l}\text { Pembuatan dana prasasti dana } \\
\text { GDM }\end{array}$ & & 1.115 .000 & 12.950 .824 \\
\hline & Terima PPN DN & 111.500 & & 13.062 .824 \\
\hline & Terima PPH Pasal 22 & 15.053 & & 13.077.377 \\
\hline 10 & Pembuatan desaign RAB & & 1.500 .000 & 11.577.377 \\
\hline \multirow[t]{4}{*}{11} & Kepada saudara anwar & & 2.700 .000 & 8.877.377 \\
\hline & Terima PPN DN & 245.455 & & 9.122 .831 \\
\hline & Terima PPH Pasal 22 & 36.818 & & 9.159 .649 \\
\hline & JUMLAH & 81.374 .649 & 72.215 .000 & 9.159.649 \\
\hline
\end{tabular}

Sumber: Laporan Pertanggungjawaban Dana GDM Tahap I Tahun 2017 Pembangunan Madrasah

Pemerintahan Lubuk Beringin dalam realisasi anggaran dana GDM Tahap 1 Tahun 2017 telah diterima dengan jumlah Rp. 75.000.000 dan digunakan dengan tertib anggaran yang di perincikan penggunaannya seperti di atas sehingga uang keluar dengan jumlah Rp. 72.215.000 dan uang yang tersisa pada saldo berjumlah Rp. 9.159.649.

Dusun Timbolasi dalam merealisasikan dana GDM Tahap I tahun 2017 yaitu untuk pembangunan Sekolah dengan rincian sebagai berikut: 
Tabel 14. Pelaksanaan Dana GDM Tahap I Tahun 2017 Oleh Dusun Timbolasi

\begin{tabular}{|c|c|c|c|c|c|}
\hline No & Uraian & $\begin{array}{l}\text { Penerimaan } \\
(\mathrm{Rp})\end{array}$ & $\begin{array}{l}\text { Pengeluaran } \\
\text { (Rp) }\end{array}$ & SaldoAwal & $\begin{array}{l}\text { Saldo } \\
\text { Akhir }\end{array}$ \\
\hline 1 & $\begin{array}{l}\text { Terima dana transfer } \\
\text { dari SP2D dana GDM }\end{array}$ & 75.000 .000 & - & 75.000 .000 & - \\
\hline 2 & $\begin{array}{l}\text { Pembelian semen } 300 \\
\text { sak } \times 76.000\end{array}$ & & 22.800 .000 & & \\
\hline 3 & $\begin{array}{l}\text { Pembelian pasir uruq } \\
6 \mathrm{~m}^{3} \times 146000\end{array}$ & & 876.000 & & \\
\hline 4 & $\begin{array}{l}\text { Pembelian pasir beton } \\
50 \mathrm{~m}^{3} \times 167.000\end{array}$ & & 8.350 .000 & & \\
\hline 5 & $\begin{array}{l}\text { Pembelian kerikil } 70 \\
\mathrm{~m}^{3} \times 214.000\end{array}$ & & 14.980 .000 & & \\
\hline 6 & $\begin{array}{l}\text { Pembelian papan cor } \\
8 \mathrm{~m}^{3} \times 150.000\end{array}$ & & 12.000 .000 & & \\
\hline 7 & $\begin{array}{l}\text { Pembelian paku } 20 \mathrm{~kg} \\
\text { × } 20.000\end{array}$ & & 400.000 & & \\
\hline 8 & $\begin{array}{l}\text { Pembelian cangkul } 2 \\
\text { buah }\end{array}$ & & 150.000 & & \\
\hline 9 & $\begin{array}{l}\text { Pembuatan papan } \\
\text { kegiatan }\end{array}$ & & 279.000 & & \\
\hline 10 & Upah tukang pekerja & & 13.000 .000 & & \\
\hline 11 & $\begin{array}{l}\text { Membuat desaign } \\
\text { RAB }\end{array}$ & & 1.500 .000 & & \\
\hline & JUMLAH & 81.374 .649 & 74.335 .000 & 75.000 .000 & 665.000 \\
\hline
\end{tabular}

\section{Sumber: Laporan Pertanggungjawaban Dana GDM Tahap I Tahun 2017 Pembangunan Madrasah}

Dari data di atas Pemerintahan Dusun Timbolasi dalam realisasi anggaran dana GDM Tahap 1 Tahun 2017 telah di terima dengan jumlah Rp. 75.000.000 dan digunakan dengan tertib anggaran yang di perincikan penggunaannya seperti di atas sehingga uang keluar dengan jumlah Rp. 74.335.000 dan uang yang tersisa pada saldo berjumlah Rp. 665.000.

Namun dalam penyusunan dokumen Pemerintah dusun sangat kesulitan karena dokumen yang dilampirkan sangat banyak. Prosedur ini sebenanarnya berbelit untuk diterapkan pada pemerintahan dusun. Pemerintahan dusun akan kewalahan untuk mengurusi dokumen-dokumen dengan fasilitas dan SDM seadanya. Dengan kondisi di dusun yang terbatas tentu saja Sistem yang ada saat ini sangat tidak relevan dengan jumlah dusun yang banyak, sedangkan anggota faskab hanya sedikit, kondisi ini tambah di persulit dengan jarak setiap dusun yang jauh jika ada revisi. 
Dusun Sinamat Ulu sama sekali tidak memberikan laporan pertanggunjawabanya, hal ini menjadi penyelidikan oleh inspektorat terkait penggunaan dana GDM di Dusun Sinamat Ulu, menurut DMPD Situasi ini disebabkan karena jauhnya lokasi dusun sehingga menghambat pembinaan dan pengawasan yang dilakukan oleh pemerintahan kabupaten, dan disebabkan juga jumlah SDM pemerintah kabupaten untuk dapat secara berkala memberikan pembinaan karena sangat banyak desa yang harus di urus yaitu sebanyak 141 desa yang diantara memiliki akses yang sangat sulit. Kemudian hal ini juga disebabkan karena SDM yang kurang memadai pada pemerintahan tingkat dusun karena terbatasnya akses informasi dan pendidikan.

Tabel 15. Komparasi Adanya Laporan Pertanggungjawaban di Dusun Lubuk Beringin, Timbolasi dan Sinamat Ulu

\begin{tabular}{clccc}
\hline No & $\begin{array}{c}\text { Adanya Laporan } \\
\text { Peretanggungjawaban }\end{array}$ & $\begin{array}{c}\text { Dusun Lubuk } \\
\text { Beringin }\end{array}$ & $\begin{array}{c}\text { Dusun } \\
\text { Timbolasi }\end{array}$ & $\begin{array}{c}\text { Dusun } \\
\text { Sinamat } \\
\text { Ulu }\end{array}$ \\
\hline 1 & Laporan realisasi dana GDM & Ada & Ada & Tidak ada \\
2 & Adanya Dokumen LPJ & Ada & Ada & Tidak ada \\
\hline
\end{tabular}

Maka perbandingan dalam pelaporan pertanggungjawaban untuk Dusun Lubuk Beringin dan dusun Timbolasi telah dilaksanakan dengan baik walaupun pemerintah dusun sangat kesulitan dalam melaksanaknnya, bebeda halnya dengan Dusun Sinamat Ulu yang tidak melakukan perlaporan pertanggungjawaban sama sekali.

\section{PENUTUP}

\section{Kesimpulan}

Berdasarkan hasil analisis dari penelitian tentang Akuntabilitas Politik dalam anggaran publik dana GDM di Kabupaten Bungo, bahwa Pemerintah Kabupaten Bungo telah Akuntabel kerena Bupati terpilih telah merealisasikan janji politiknya yaitu memberikan pendanaan kepada setiap dusun dengan jumlah Rp. 250.000.000 per dusun. Kemudian terkait legalitas pertanggungjawaban telah ada yang tertulis di dalam Perbub Nomor 5 Tahun 2017 yaitu terdapat aturan dan sanksi yang legal terhadap pelaksanaan dana GDM dan adanya komitmen beputi untuk menjalankan dana GDM dengan sebaiksebaiknya yaitu sudah ada juga tertuang di dalam Perbub Nomor 5 tahun 2017.

Namun dalam realisasi jumlah nominal pendanaan yang di berikan oleh dusun berbeda dengan janji kampanye yaitu seharusnya pendanaan diberikan dengan jumlah Rp. 250.000.000 namun untuk pencairan Tahap I hanya Rp. 150.000.0000 hal ini disebabkan karena dana GDM merupakan program yang baru saja dilaksanakan yang memiliki resiko yang tinggi apabila terjadi kesalahan dalam tahap awal penggunaannya, 
maka sembari mendapatkan strategi yang benar-benar sesuai dengan situasi dan wilayah pada dusun-dusun di Kabupaten Bungo, Pemerintah Muara Bungo melaksanaankan dengan jumlah pendanaan yang belum full seluruhnya hal ini dilakukan juga agar dapat melihat hasil dari pelaksanaan di awal akan seperti apa dan menjadi bahan evaluasi.

Legalitas pertanggungjawaban, dari analisa kasus yang terjadi pada Dusun Sinamat Ulu pemerintah kabupten telah memberikan sanksi terhadap dusun tersebut namun dengan porsi kesalahan yang telah dilakukan seharusnya sanksi yang diberikan tidak hanya sekedar sanksi teguran lisan atau penundaan pendanaan, namun harus dapat di proses secara hukum, karena permasalahan di dusun tersebut dalam penggunaan dana GDM tidak jelas arahnya, dan sama sekali acuh terhadap peraturan yang telah di tetapkan, yang mana pengelolaan keuangan di dusun merupakan tanggung jawab Rio tersebut. Walaupun tidak dapat di pungkiri bahwa jauh dan sulitnya akses menuju ke dusun tersebut justru seharusnya harus mendapatkan perhatian khusus dari pemerintah kabupaten. Kemudian bupati terpilih telah berkomitmen dalam pelaksanaan dan GDM karena telah terealisasinya dalam segi pendanaan, system, maupun pengorganisasian GDM yang seluruhnya telah tertuang di dalam Perbub Nomor 5 Tahun 2017 Tentang Pedoman dan Petunjuk Teknis Pelaksanaan dana GDM.

Perbandingan antara Dusun Lubuk Beringin dan Tombolasi telah sama-sama akuntabel dalam penggunaan dana GDM, karena telah melaksanakan penyususan dokumen perencanaan dengan partisipatif, serta realisasi anggaran yang terdokumentasikan pada RAB dengan baik dan terperinci, begitu juga dengan bangunan fisik yang tampak, kemudian dokumen laporan pertanggungjawaban seluruhnya telah dilaksanakan beserta melakukan transparansi berupa papan informasi pelaksanaan didalam area pembangunan.

Namun hal yang berbeda terdapat di Dusun Sinamat Ulu Pemerintahan ini sama sekali tidak akuntabel, karena realisasi anggaran yang fiktif, tidak melaksanakan pelaksanaan dokumen perencanaan, tidak melakukan musyawarah, bahkan tidak sama sekali memberikan laporan pertanggungjawaban sedangkan dalam pencairan dana GDM tahap I dengan merata telah diberikan oleh Pemerintah Kabupaten Bungo.

Situasi ini disebabkan karena jauhnya lokasi dusun sehingga menghambat pembinaan dan pengawasan yang dilakukan oleh pemerintahan kabupaten, dan disebabkan juga jumlah SDM pemerintah kabupaten untuk dapat secara berkala memberikan pembinaan karena sangat banyak desa yang harus di urus yaitu sebanyak 141 desa yang diantara memiliki akses yang sangat sulit. Kemudian hal ini juga disebabkan karena SDM yang kurang memadai pada pemerintahan tingkat dusun karena terbatasnya akses informasi dan pendidikan. 


\section{Saran}

Berdasarkan kesimpulan diatas, maka didapatkan beberapa saran/rekomendasi sebagai berikut:

1. Rekomendasi Kepada Pemerintah Kabupaten Bungo

Dalam hal ini pemerintahan dusun mengaku kesulitan dengan sistem yang ada sekarang karena sangat banyak dokumen yang harus disusun, hal menyebabkan pemerintahan dusun hanya sibuk mengurusi administrasi namun dalam pelaksanaan pembangunan yang nyata menjadi kurang maka dari itu Pemerintah Kabupaten sebaiknya dapat memberikan sistem yang lebih ringkas dan mudah untuk diaplikasikan oleh Pemerintah Dusun namun dapat di petanggungjawabkan, karena tidak semua dusun mendapat akses yang mudah untuk menjalankan sistem yang ada sekarang, karena sebagian dusun memiliki jarak tempuh yang jauh, SDM yang tidak memadai, akses informasi sulit.

Kemudian SDM dari pemerintahan kabupaten untuk melakukan pengawasan dan pembinaan masih sangat kurang atau tidak sebanding, sedangkan jumlah dusun yang harus diurusi adalah sebanyak 141 dusun. Sedangkan tim Faskab sebagai sepervisior hanya berjumlah 4 (empat) orang yang terdiri dari 1 (satu) koordinator dan 3 fasilitator. Maka pemerintah kabupatan sebaiknya menambahkan SDM untuk lebih efektif melakukan pengawasan dan pembinaan pada setiap dusun yang jumlahnya sangat banyak agar dapat sebanding. Kemudian dalam meberikan peraturan dan sanksi sebaiknya pemerintah kabupaten menjelaskan dengan jelas dan tegas kepada pemerintahan dusun atau dalam hal ini yaitu Rio sebagai penanggungjawab pelaksanaan di dusun jika melakukan penyimpangan terhadap penggunaan dana GDM maka harus di hukum penjara.

Pemerintah kabupaten sebaiknya berkoordinasi dengan pemerintahan kecamatan untuk selalu dengan aktif memberikan pembinaan, kontrol, serta pengawasan kepada setiap dusun, namun yang diutamakan dan memberikan perhatian khusun kepada dusun yang benar-benar memiliki akses yang sulit.

\section{Rekomendasi Kepada Pemerintah Dusun}

Sebaiknya pemerintah dusun dalam penggunaan dana GDM dapat mengarahkan penggunaannya pada pembangunan yang produktif dalam segi ekonomi masyarakat contohnya adalah pembangunan jalan keperkebunan karet atau sawit masyarakat dan membangun pariwisata dusun dengan memanfaatkan potensi alam yang ada di dusun. Kemudian sebaiknya pemerintahan desa dapat selalu dapat berkoordinasi kepada pemerintahan kabupaten terkait kendala, dan kesulitan yang dihadapi di dusun sehingga pemerintah dusun selalu mendapat referensi dalam membangun sistem GDM yang lebih baik. 


\section{REFERENSI}

Marijan Kacung. 2010. Sistem Politik Inonesia: Konsolidasi Demokrasi Pasca Orde Baru. Jakarta: Kencana Prenada Media Group.

Mardiasmo. 2002. Akuntansi Sektor Publik. Penerbit Andi. Yogyakarta.

Abimanyu. 2005. Analisis Pengaruh Dana Alokasi Umum dan Pendapatan Asli Daerah terhadap Prediksi Belanja Daerah: Studi Empirik di Wilayah Provinsi Jawa Tengah \& DIY. JAAI, Vol. 08, No. 2.

Moloeng. 2009. Metodologi Penelitian Kualitatif. Bandung: Remaja Rosdakarya.

Mardiasmo. 2009. Akuntansi Sektor Publik, Yogyakarta: ANDI.

Bppk. 2015. Petunjuk Pelaksanaan Bimbingandan Konsultasi Pengelolaan Keuangan Desa. Tim penyusun: Deputi Bidang Pengawasan Penyelenggaraan Keuangan Daerah.

PujiAgus, dan Madya widyaiswara. 2015: JUKLAK BIMKON Pengelolaan Keuangan Desa: Sistem dan Prosedur Pertanggungjawaban Keuangan Desa. Didalam http:// bppk.kemenkeu.go.id/diakses 20/10/2016 Pukul 23:32.

Jane Linda. 1991. Reporting of Governmental Performance Indicators For Assessment of Public Accountability. Desertasi Publik Admistrasi, Arizona State University.

Griffin, Charles C. 2010. Lives in the Balance: Improving Accountability for Public Spending in Developing Countries. Whashington DC: Broking Intitutions Press.

Katrina. 2006. Making Public Finance Public: Subnational Budget Wacth in Croatia, Macedonia, and Ukraine. Hungary: Local Government and Public Service Reform Initiative.

Davey, Kenneth. 2009. Making Government Accountable: Local Government Audit in Postommunist Europa. Hungary: Local Government and Public Service Reform Initiative. Jordan, dkk. 2006. NGO Accountability: Politic, Principles and Innovation. London : Earth Scan.

Heywood Andrew. 2013. Politik: Edisi Keempat.Yogyakarta: Pustaka Pelajar.

Dahl. Modern Political Analysis.

Inu K. Syafiie. 2013. Ilmu Pemerintahan. Bandung: Mandar Maju

Hoogerwert. 1985. Politikologi (Polititologie). Jakarta: Erlangga

Thoha Miftha. 1984. Dimensi-dimensi prima Ilmu Administrasi Negara. Jakarta: Rajawali. Harvard Law Review. 1994. Federalism, Political Accountability, and the Spending Clause.

The Harvard Law Review Association, Vol. 107, No 6.

Joy Marie Moncrieffe. 1998. Reconceptualizing Political Accountability. Sage Publications,

Vol. 19, No. 4.yang

John S. Thomas. 1975. Government Accountability: For What?. Taylor \& Francis, Ltd, Vol.

1, No. 2.

Radoslaw. 2006. Accountability and Institutional Design in New Democracies. International Journal of Sociology, Vol. 36, No. 2.

Arce Alberto. 2009. Accountability Politics: Power and Voice in Rural Mexico by Jonathan Fox. Journal of Latin American Studies, Vol. 41, No. 1, hal 193-194. 
Ladipo Omowunmi, dkk. 2009. Accountability in Public Expenditures in Latin America and the Caribbean Revitalizing Reforms in Financial Management and Procurement. Washington DC: The World Bank.

Scarparo Simona. 2008. Accountability in the UK devolved parliament and assemblies. USA and Canada: Routledge.

Novianti, dkk. 2015. Politik Komisi Pemilihan Umum Daerah Pada Pelaksanaan Pilkada 2010 Kabupaten Situbondo. Junal Ilmu Sosial dan Ilmu Politik, Vol. 4, No. 3.

Nafidah, dkk. 2017. Akuntabilitas Pengelolaan Keuangan Desa di Kabupaten Jombang. Akuntabilitas: Jurnal Ilmu Akuntansi, Vol 10, No. 2.

Wicaksono Widya. 2015. Akuntabilitas Organisasi Sektor Publik. Jurnal Kebijakan \& Administrasi Publik, Vol 19, No. 21.

Mulgan Richard. 2017. Accountability in Multilevel Governance: The Example of Australian Federalism. Conceptual challenges and case studies from Australia: ANU Press.

Baharudin. 2013. Akuntabilitas Pelayanan Publik: Studi Kasus Pelayanan Perizinan Mendirikan Bangunan di Kota Makassar. Jurnal Ilmu Sosial dan Ilmu Politik, Vol. 31, No. 2.

Goodhart Michael. 2011. Democratic Accountability in Global Politics: Norms, not Agents. The University of Chicago Press on behalf of the Southern Political Science Association, Vol 71, No. 1.

Lyne. 1960. The Voter's Dilemma and Democratic Accountability. The Pennsylvania State University Press, University Park.

Aan Jaelani. 2015. Management Of Public Finance In Indonesia: Review of Islamic Public Finance.

Musgrave, dkk. 1989. Public Finance in Theory and Practise. Mc Graw Hill Book Company. Buchanan. 1967. Public Finance in Democratic Process. Chapel Hill, N.C : University of North Carolina Press.

Harvey. 2002. Public Finance: Essay for the Encyclopedia of Public Choice. Princeton University: CEPS Working Paper.

BPHN, Kementerian Hukum dan HAM Republik Indonesia, www.bphn.go.id.

Indradi Sjamsiar. 2017. Etika Birokrasi dan Akuntabilitas Pemerintahan: Manajemen Birokrasi dan Akuntabilitas Sektor Publik. Malang: Intrans Publising.

Halim Abdul. 2012. Pengelolaan Keuangan Daerah. Yogyakarta: UPP STIM YKPN. 